\title{
Co-occurrence of gray whales and vessel traffic in the North Pacific Ocean
}

\author{
Gregory K. Silber ${ }^{1, *}$, David W. Weller ${ }^{2}$, Randall R. Reeves ${ }^{3}$, Jeffrey D. Adams ${ }^{4}$, \\ Thomas J. Moore ${ }^{5}$ \\ ${ }^{1}$ Smultea Environmental Sciences, Washington Grove, MD 20880, USA \\ ${ }^{2}$ Marine Mammal and Turtle Division, Southwest Fisheries Science Center, National Marine Fisheries Service, NOAA, \\ La Jolla, CA 92037, USA \\ ${ }^{3}$ Okapi Wildlife Associates, Hudson, Quebec J0P1H0, Canada \\ ${ }^{4}$ Office of Protected Resources, National Marine Fisheries Service, NOAA, Silver Spring, MD 20910, USA \\ ${ }^{5}$ Independent Researcher, Seattle, WA, USA
}

\begin{abstract}
All species of large whales are susceptible to vessel strikes, but the true scale and geographical extent of such strikes is not known. This paper provides a qualitative assessment of the range-wide risks posed to gray whales Eschrichtius robustus by vessels, by comparing patterns of whale distribution with the density of vessel traffic seasonally throughout the North Pacific in 2019. Areas of very high vessel density were evident year-round near many coastlines, along inter-continental trade routes, and at hubs of commercial shipping near port entrances. Gray whales were exposed to vessel strikes throughout their range and in their feeding, southbound migration, wintering, and northbound migration periods. Areas of apparently high risk were in the Russian Far East (Kamchatka peninsula and Okhotsk Sea), Bering Sea (including the Aleutian Islands), Gulf of Alaska, and along the entire west coast of North America. Risk appeared greatest during south- and northbound migration when much of the gray whale population is moving through waters near shore. Tanker, container, and bulk-carrier ships represent considerable risk to whales in the North Pacific Ocean, but the large geographical extent of commercial fishing activities suggests that fisheries are also a substantial source of risk. Vessel-strike risk maps indicate the relative extent of exposure of gray (and other) whales to underwater vessel noise. The number of gray whales killed by ship strikes each year may be in the tens, or perhaps the low hundreds. Additional analyses, including quantitative assessments, are warranted to further clarify the risk of vessel strikes to gray whales.
\end{abstract}

KEY WORDS: Vessel-strike risk · Gray whale - Eschrichtius robustus · Ship strike · Vessel traffic · Spatio-temporal co-occurrence

\section{INTRODUCTION}

All species of large whales are susceptible to being struck by vessels (Clapham et al. 1999, Van Waerbeek et al. 2007) and vessel (or ship) strike is regarded as an important conservation concern for most of the populations that are recovering from commercial exploitation (Bettridge et al. 2015, Monnahan et al.

${ }^{*}$ Corresponding author: gregsilber2@gmail.com
2015, Thomas et al. 2016). In some endangered or depleted whale populations, such as the North Atlantic right whale Eubalaena glacialis (Kraus et al. 2005, Vanderlaan \& Taggart 2007), deaths due to ship strike have been sufficiently frequent to limit population growth (Cates et al. 2017).

In the North Pacific Ocean (NP), fatal or debilitating ship strikes have been most commonly reported,

(C) G. K. Silber, R. R. Reeves, T. J. Moore and, outside the USA, the US Government 2021. Open Access under Creative Commons by Attribution Licence. Use, distribution and reproduction are unrestricted. Authors and original publication must be credited.

Publisher: Inter-Research · www.int-res.com 
in descending order, for gray Eschrichtius robustus, humpback Megaptera novaeangliae, fin Balaenoptera physalus, and blue whales B. musculus (Jensen \& Silber 2003). Ship-strike risk has been modeled for each of these species (except gray whales) in specific portions of the NP (e.g. Williams \& O'Hara 2010, Redfern et al. 2013), but in all cases, the range-wide effects of vessel-strike mortality (and morbidity) on abundance and population growth are uncertain. Nevertheless, in the last decade or more, many species of whales in the NP that were depleted by commercial whaling have shown steady increases in abundance despite ever-increasing non-whaling threats from vessels and other human activities (Bettridge et al. 2015, Thomas et al. 2016).

In the western NP (WNP), gray whales were heavily exploited and close to extinction by the 1960s (Bowen 1974, Weller et al. 2002). Although the small population of about 200 whales that feeds off Sakhalin Island, Russia, during the summer and autumn has been increasing slowly since the late 1990s, it is listed as an Endangered sub-population on the IUCN Red List (Cooke et al. 2018). The population is also listed as endangered under the US Endangered Species Act and designated as depleted under the US Marine Mammal Protection Act. In April 2020, the Red Data Book of the Russian Federation listed the 'Okhotsk Sea population of the gray whale' as critically endangered (Reeves et al. 2020). ${ }^{\underline{1}}$

While some of the gray whales that feed off Sakhalin migrate in winter to the eastern NP (ENP), others appear to remain in the WNP and, based on photo-identification matches, migrate at least as far south as northern Japan (Weller et al. 2008, 2015, 2016). Recovery of gray whales in the WNP is a longterm conservation aspiration of the IUCN, the International Whaling Commission (IWC), international non-governmental organizations, and some governments and stakeholders in the relevant range states where gray whales occur.

The abundance of gray whales in the ENP was estimated to be nearly 27000 in 2016 (Durban et al. 2017, IWC 2018). The population grew through at least the late 1990s (Punt \& Wade 2012) followed by a decline in 1999-2000 due to an 'unusual mortality event' (UME) of unknown cause (Gulland et al. 2005). The population subsequently recovered, returning to its highest recorded abundance (Durban et al. 2017).

10rder of the Ministry of Natural Resources and Environment of the Russian Federation from 24 March 2020 No. 162 'On approval of the list of fauna objects included in the Red Data Book of the Russian Federation', ratified by the Ministry of Justice on 02.04.2020, effective from 12.04.2020
Another UME began in 2019 and continued into 2020 (https://www.fisheries.noaa.gov/national/marine-lifedistress/2019-2020-gray-whale-unusual-mortalityevent-along-west-coast\#gray-whale-strandings).

The distribution of gray whales shifts seasonally. In spring, they migrate northward primarily along coastal margins to relatively high-latitude feeding grounds. A reverse migration to wintering areas takes place in late autumn and winter using similar corridors (Rice \& Wolman 1971, Swartz 2018). From June through October, ENP gray whales feed in areas that include coastal portions of the Bering, Chukchi and Beaufort Seas (Weller et al. 2002, Swartz 2018). A small component of the ENP population (called the Pacific Coast Feeding Group, PCFG) occupies coastal foraging areas between British Columbia (Canada) and parts of Washington, Oregon, and northern California (USA) (Ford et al. 2013, Calambokidis et al. 2019). The primary known feeding areas for WNP gray whales are on the northeastern Sakhalin Island shelf in the Russian Far East and to a lesser degree in nearshore waters of southeastern Kamchatka (Weller et al. 2002, Tyurneva et al. 2010).

Southward-migrating gray whales are found throughout the Bering Sea, in parts of the Okhotsk, Chukchi, and Beaufort Seas, and in the Gulf of Alaska. They are also relatively abundant along parts of the North American coastline.

Gray whale wintering areas are largely limited to south of $32^{\circ} \mathrm{N}$ latitude. Large numbers of whales aggregate annually in shallow wintering lagoons or embayments along the west coast of Baja California, Mexico (Rice \& Wolman 1971, Swartz 2018). The species is less common, but is known to occur, in the Gulf of California and along mainland coast of Mexico south to about $15^{\circ} \mathrm{N}$ latitude (Swartz 2018). Wintering areas in the WNP are less well studied and there is uncertainty about where they are and how many whales visit them (Weller et al. 2002, 2016).

Gray whales occur primarily, but not entirely, on or near the continental shelf and in coastal waters during much of the year (Guazzo et al. 2017). Parts of their migration routes pass near large human population centers and through areas with substantial maritime activities (e.g. Moore \& Clarke 2002, Weller et al. 2002, Calambokidis et al. 2015), creating a serious risk of injury or death from vessel strikes.

Records of vessel-strike deaths and serious injuries of gray whales are compiled and reported annually in some locations (e.g. Carretta et al. 2018, Scordino et al. 2020). Multiple instances of strikes are reported every year. However, the data are limited primarily to jurisdictions where regular reporting systems are 
in place (e.g. the US Marine Mammal Health and Stranding Response Program, www.fisheries.noaa. gov/national/marine-life-distress/marine-mammalhealth-and-stranding-response-program; and the Marine Mammal Response Program under Canada's Species at Risk Act, www.dfo-mpo.gc.ca/speciesespeces/mammals-mammiferes/program-programme/ index-eng.html) and thus do not represent the true scale and geographical extent of strikes. Further, most records of vessel-struck large whales come from stranded carcasses (Laist et al. 2001, Jensen \& Silber 2003), but carcass detection and reporting are undoubtedly incomplete (Kraus et al. 2005, Punt \& Wade 2012, Rockwood et al. 2017).

This paper provides a qualitative assessment of the range-wide risks posed to gray whales by vessels. The approach used was to compare patterns of whale distribution with heat maps of the density of vessel traffic seasonally throughout the NP in 2019. This analysis was used to determine where the risks are likely most acute and therefore where more detailed, focused efforts at quantitative risk assessment, followed by risk reduction and mitigation measures, might be warranted.

\section{METHODS}

Gray whale range data were extracted from source data associated with published maps showing generalized patterns of the occurrence and movements of gray whales during the 4 main (and overlapping) seasons of their annual cycle: summer-autumn feeding (June-October), southbound migration (NovemberJanuary), wintering (January-March), and northbound migration (February-May) (IWC 2017)르. The 4 seasons were defined on the basis of general references on gray whale phenology (e.g. Rice \& Wolman 1971, Rugh 1984, Swartz 2018). The periods used in the analysis are imprecise and are dynamic to some degree in both space and time, but generally capture the annual migration cycles of gray whales. The maps depicting 2019 vessel traffic and associated vesselstrike risk were aligned with these same seasonal/behavioral periods.

ArcGIS Desktop software (version 10.7.1) was used to perform data conversion from Keyhole Markup Language (KML) format to vector features in the file geodatabase format. Most of the source data for gray whale distributions were represented by geographical areas (i.e. polygonal data). However, the migration corridor along the WNP coastline was represented by an offshore linear feature in the KML-formatted data. We transformed this linear feature in ArcGIS to vector polygons by using the Buffer Tool and a 10 nautical mile (n mile) geodesic distance on each side. Depending on the original placement of the linear feature in the KML-formatted data relative to the coastline, this produced a roughly $20 \mathrm{n}$ mile wide migration corridor (this band was somewhat wider in some areas where adjustments were necessary to extend the polygon to the coastline).

The volume and distribution of vessel traffic coinciding with the occurrence of gray whales in the NP were derived from Automatic Identification System (AIS) data. The International Maritime Organization (IMO) requires AIS capabilities on all vessels of 300 gross tons (GT) and greater that make international voyages and all vessels $150+$ GT that are carrying 12 or more passengers on an international voyage. ${ }^{\mathbf{3}}$ Therefore, we assume that our data include trip information for all vessels $\geq 300$ GT due to the IMO carriage requirements. The data also include vessels smaller than this tonnage threshold because some vessels transmit AIS signals for safety-of-navigation purposes.

A vessel with AIS capabilities broadcasts messages containing information on its identity and characteristics, as well as messages containing its position, speed, and direction of travel using low-power, very high-frequency radio signals (Tetreault 2005, Robards et al. 2016). For this analysis, we used satellite AIS data obtained from ORBCOMM for the full calendar year 1 January to 31 December 2019 for the NP between 10 and $80^{\circ} \mathrm{N}$ latitude.

AIS signals generally include information about vessel type and size. However, given that our intent was to characterize strike risk from all vessel types

\footnotetext{
${ }^{2}$ These maps were produced under the joint aegis of the Scientific Committee (SC) of the International Whaling Commission and the Western Gray Whale Advisory Panel of the IUCN. Their content was based on review of literature and elicitation of expert knowledge during SC and IUCN workshops. They are also available at: https://www.iucn. org/western-gray-whale-advisory-panel/about-gray-whales/ rangewide-conservation-issues; and at https://iwc.int/ western-gray-whale-cmp

${ }^{3}$ The US Coast Guard expanded the IMO mandate by requiring AIS on vessels that operate in US waters and meet the following criteria: self-propelled vessels $20+\mathrm{m}$ (65+ feet) in length engaged in commercial service, towing vessels $8+\mathrm{m}(26+$ feet) in length with more than 600 horsepower engaged in commercial service, and self-propelled vessels certified to carry more than 150 passengers (33 [US]CFR $\S 164.46)$. In May 2019, Canada expanded AIS carrying requirements to include vessels carrying more than 12 passengers or vessels $8 \mathrm{~m}$ or more in length and carrying passengers. https://tc.canada.ca/sites/default/files/migrated/ssb_09_ 2019e.pdf
} 
based solely on overlap of whales and vessel traffic, no attempt was made to analyze ancillary information regarding vessel types. Nonetheless, it is possible to draw inferences about vessel type based on features of route and traffic patterns depicted in heat maps. For example, fishing operations could be inferred from clusters of relatively intense vessel activity that do not exhibit clear 'point A to point B' transits that are characteristic of shipping routes. Fishery activities were also inferred from various published sources (e.g. FAO 2017, Lowry et al. 2018). Seismic surveys and research cruises can be evident as systematic grid lines in a finite area; and vessel activity associated with oil and gas development can be inferred around known facilities and platforms (e.g. Sakhalin; Reeves et al. 2005, IUCN 2020). Accordingly, heat maps were used in general descriptions of activities of various vessel types and the risk those vessel types represent, as discussed in Section 3.1 below.

Raw AIS data were decoded into monthly commaseparated value files using the Transview (TV32) software application developed by the US Department of Transportation's Volpe National Transportation Systems Center (www.volpe.dot.gov). These data were then imported into a spatially enabled PostgreSQL database. For this analysis, any AIS transmissions that indicated vessel speeds of less than 0 knots or greater than 50 knots were removed, as those data obviously contained errors. Temporally adjacent AIS transmissions belonging to the same vessel were aggregated into transits if the time elapsed between the transmissions was less than $4 \mathrm{~h}$. If the elapsed time was greater than $4 \mathrm{~h}$, a new vessel transit was started. The geometric distance between adjacent transmissions in a transit was checked against a computed distance value obtained using the elapsed time and rate of speed between the 2 transmissions. If the difference between the geometric and computed distance exceeded $5 \mathrm{n}$ miles per hour of travel, the segment resulting from joining the adjacent transmissions was flagged and removed from the final analysis because the reported raw data likely contained an error.

Shortcomings in the vessel data set for the East China, South China, and Yellow Seas are described in Section 4. Nonetheless, these areas were included in vessel density and risk maps using a demarcation set at $10^{\circ} \mathrm{N}$ latitude, northward, to accommodate possible gray whale occurrence basin-wide.

Monthly vessel-traffic data were summarized into $10 \times 10 \mathrm{~km}$ grid cells using the EASE-Grid 2.0 Northern Hemisphere, Lambert Azimuthal (EPSG: 6931) equal-area projection (Brodzik et al. 2014). For each cell, the cumulative amount of time (operational hours) spent by all vessels was calculated by summing the elapsed time associated with all vessel transit segments (geometric features created by connecting temporally adjacent AIS transmissions) located within the grid cell. Elapsed times were interpolated for transit segments that crossed grid-cell boundaries using the ratio of the transit-segment distance located within the respective grid cells (i.e. distance within cell/transit segment distance). While vessel characteristics such as vessel type, size, gross tonnage, speed, and country of registration are included in AIS messages, our intent was to characterize strike risk from all vessel types based solely on overlap of whales and vessel traffic. As such, no attempt was made to parse vessel traffic by vessel characteristics such as vessel type or size.

The gridded, monthly cumulative operational hours were then summed for each of the 4 periods noted earlier. Some of the periods have overlapping months, and all periods have a different number of total days (feeding $=153$, wintering $=90$, northbound migration $=120$, southbound migration $=92$ ), so the cumulative operational-hours value in each grid cell was normalized by the number of days in the period. These daily means for each grid cell were then logtransformed, which resulted in a normal distribution of vessel traffic data across the NP grid for each period.

To characterize the vessel-traffic density distribution spatially throughout the NP, we used 5 classes in ArcGIS generated by the natural breaks method (or Jenks optimization method). The breakpoints are standardized for all periods, to ease cross-period comparisons, based on the values from the wintering period. We also projected the data using the Equal Earth Asia Pacific projection (EPSG: 8859), with a modified central meridian of $180^{\circ}$, for better presentation oriented for the Pacific Ocean basin, while continuing to preserve area designations with equalarea characteristics.

Assessments of relative risk were performed by focusing attention on the regions where gray whales were expected to have some level of exposure to vessel traffic based on known, possible, or historical use patterns documented in the literature. An acknowledged limitation of this analysis is a paucity of finescale data on the spatial occurrence of gray whales in some locations. A reliance on generalized maps of seasonal whale occurrence (i.e. where whales might be expected to occur) was a means to generate qualitative assessments of risk. 
We used the Clip Tool in ArcGIS to extract the vessel traffic data (documented in Fig. 1) that overlaid these seasonally relevant gray whale regions. The same breakpoints used for the vessel-traffic distribution mapping were the basis for this relativerisk mapping, except that the data from the bottom 3 classes were collapsed into 1 class and the aforementioned highest class was split into 2 classes (very high and extremely high) based on a new breakpoint value that was defined as the mean plus 3 standard deviations. Few places in the entire area examined where gray whales are known to occur on a regular basis had little or no vessel activity. Therefore, to account for varying exposure scenarios for gray whales based on geographic uncertainty, we differentiated the risk classification based on known whale-use areas versus potential whale-use areas (the latter category representing areas deemed to have probable, possible, occasional, or historical whale presence). These data provided an ordinal ranking of relative vessel-strike risk based on the likelihood of co-occurrence of vessel traffic and gray whales (see Table A1 in the Appendix for additional detail on category designations).

\section{RESULTS}

\subsection{Vessel-density and risk maps}

Vessel traffic was extensive throughout the entire NP in 2019 (Fig. 1), as thousands of vessels made tens of thousands of trips. Few places in the entire area examined had little or no vessel activity. Vesseltraffic densities were high along nearly all Asian and North American mainland coastlines as well as a number of insular areas. High-density hubs of commercial shipping near port entrances and inter-continental trade routes were evident year-round. Concentrations of geographically vast vessel activity attributable primarily to large-scale regional shipping, commercial fishing, and industrial operations were situated on continental shelves (Fig. 1).

Alignment of whale and vessel distribution indicated that the risk of vessel strikes to gray whales exists throughout the range and during all phases of the annual cycle: migration, feeding, and wintering (Fig. 2). However, the relative degree of risk differed spatially and temporally, corresponding to whale movement patterns and areas of seasonally high whale density. Overall, risk appears highest during north- and southbound migration owing to the coincidence of whale occurrence and vessel activities involving long transits, concentration near major transportation centers, and clustering of commercial fishing operations.

While our study focused on the risk of vessel strikes, areas of high vessel-strike risk also indicate where gray whales are most exposed to elevated underwater noise from vessels. In addition, the vessel-density maps provide indications of vessel-strike risk to other baleen whale species whose ranges overlap with high-density vessel traffic.

\subsection{Feeding areas}

Overall, the volume of vessel activity appeared highest during the feeding season, with very high densities along nearly all Asian and North American coastlines (Fig. 1a). Notably high concentrations of vessel activity were evident along the Kamchatka peninsula, in other portions of the Okhotsk Sea, and in the western Bering Sea. In the ENP, vessel activity was most pronounced along portions of the Alaskan coastline and the entire British Columbian and western US seaboards. Traffic in the central NP, Bering Sea, and southern Gulf of Alaska was dominated by vessels engaged in trips between Asian and North American ports, and such traffic appeared heavier in the feeding period than in the others. Coastal portions of the Chukchi and western Beaufort Seas also exhibited relatively high vessel densities.

High-risk locations during the feeding period were observed in the western Bering Sea and along the east coast of the Kamchatka peninsula (Fig. 2a,b). An area of relatively high risk was also evident off northeastern Sakhalin Island (Fig. 2a). A region extending seaward hundreds of kilometers from the Chukotka and northeastern Kamchatka coasts was among the areas of highest risk and largest spatial extent (Fig. 2b). Risk appeared to be very high off Kodiak Island and along the coasts of Vancouver Island and the northwestern US mainland (Fig. 2c). Areas of moderate risk were located around the other British Columbian islands and in southeast Alaska.

Except for a few locations, vessel transits in most of the northern Bering Sea and in the Chukchi and Beaufort Seas apparently pose only a moderate risk to gray whales during this season. However, relatively small pockets of high risk were indicated along the Russian Chukchi Sea coastline and in nearshore waters of Norton Sound, Kotzebue Sound, and elsewhere along the western and northern Alaska coastlines (Fig. 2b,c). 
a

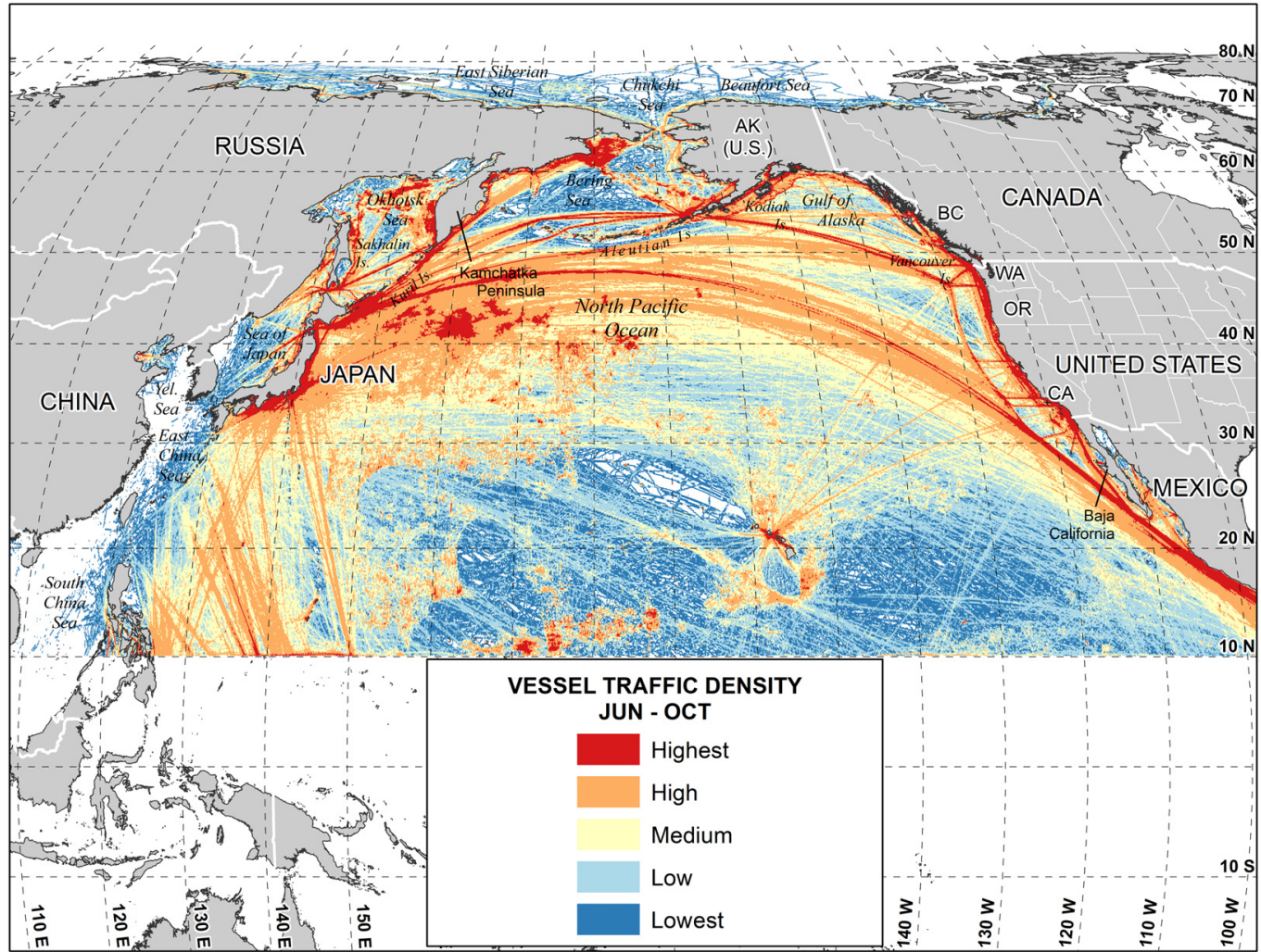

b

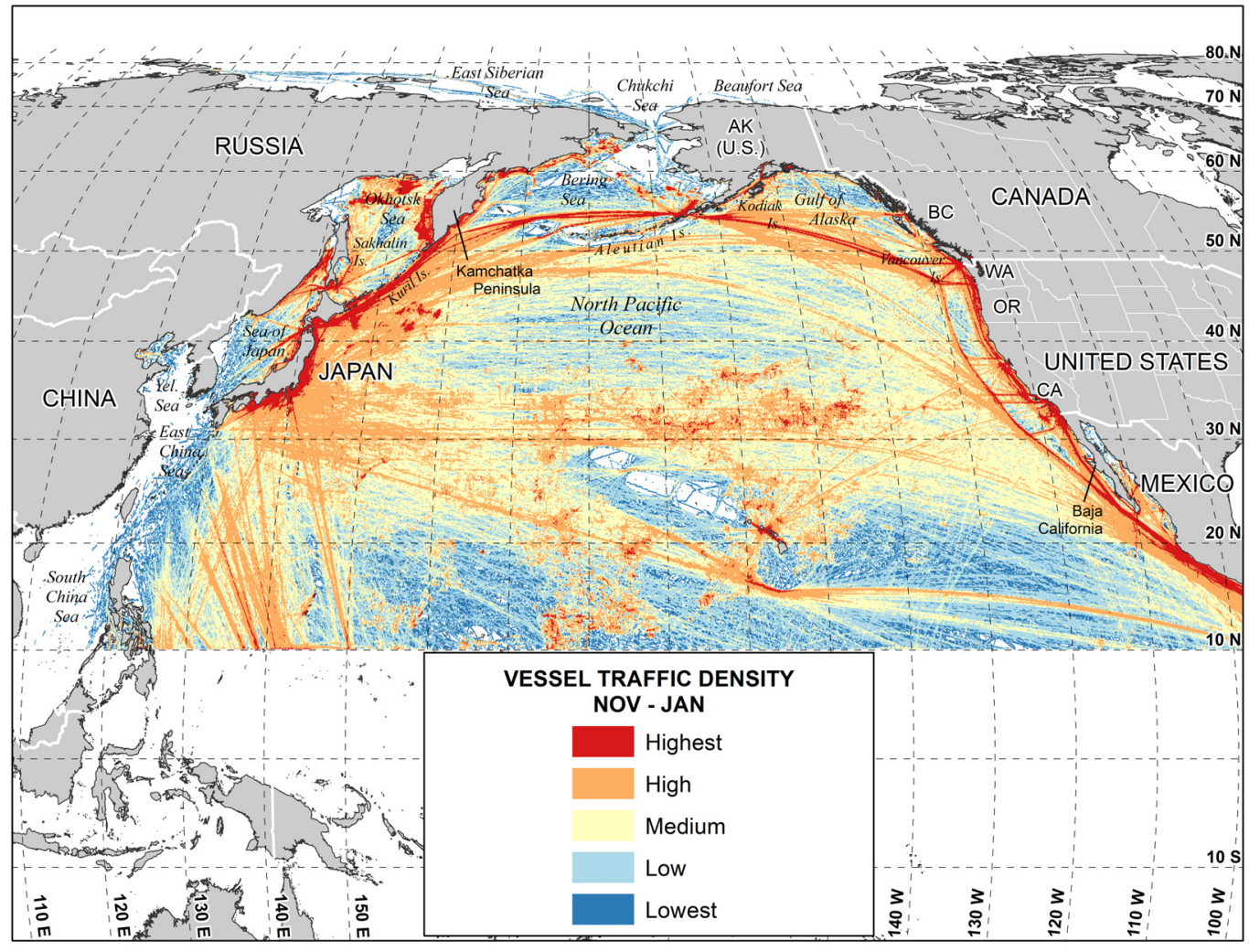

Fig. 1. Relative densities of vessel activity in 2019 shown as hours of operation per $10 \times 10 \mathrm{~km}$ grid cell. Traffic densities are roughly aligned with the gray whale annual migration cycle: (a) summer-autumn feeding (June-October), (b) southbound migration (November-January), (c) wintering (January-March), and (d) northbound migration (February-May). (See Section 2 for additional description of the location and timing of these periods.) The scale codes for vessel operational hours range from $0 \mathrm{~h}$ (white) to maximum activity (red). See Table A1 in the Appendix for divisions used for numerical vessel activity density classes 
C

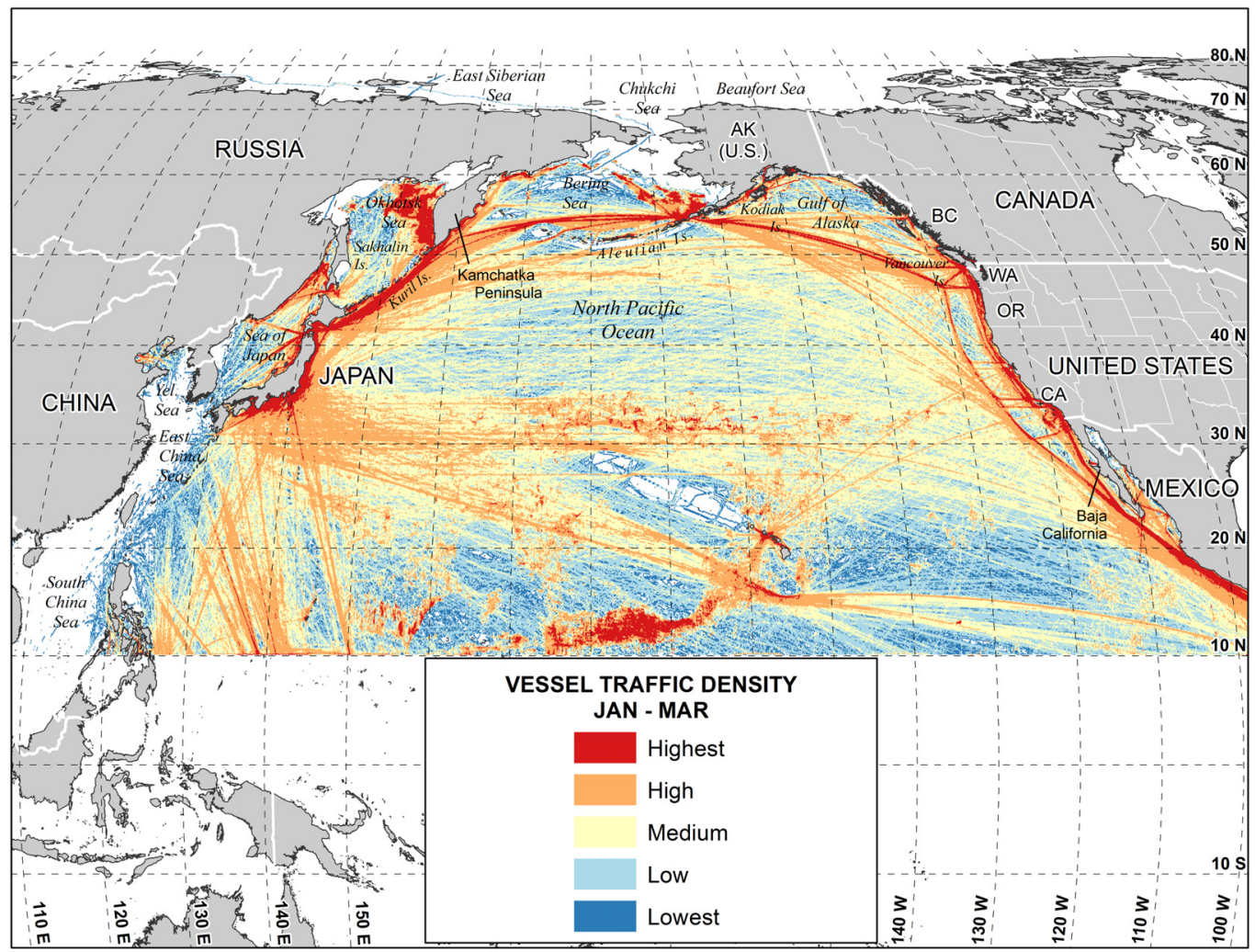

d

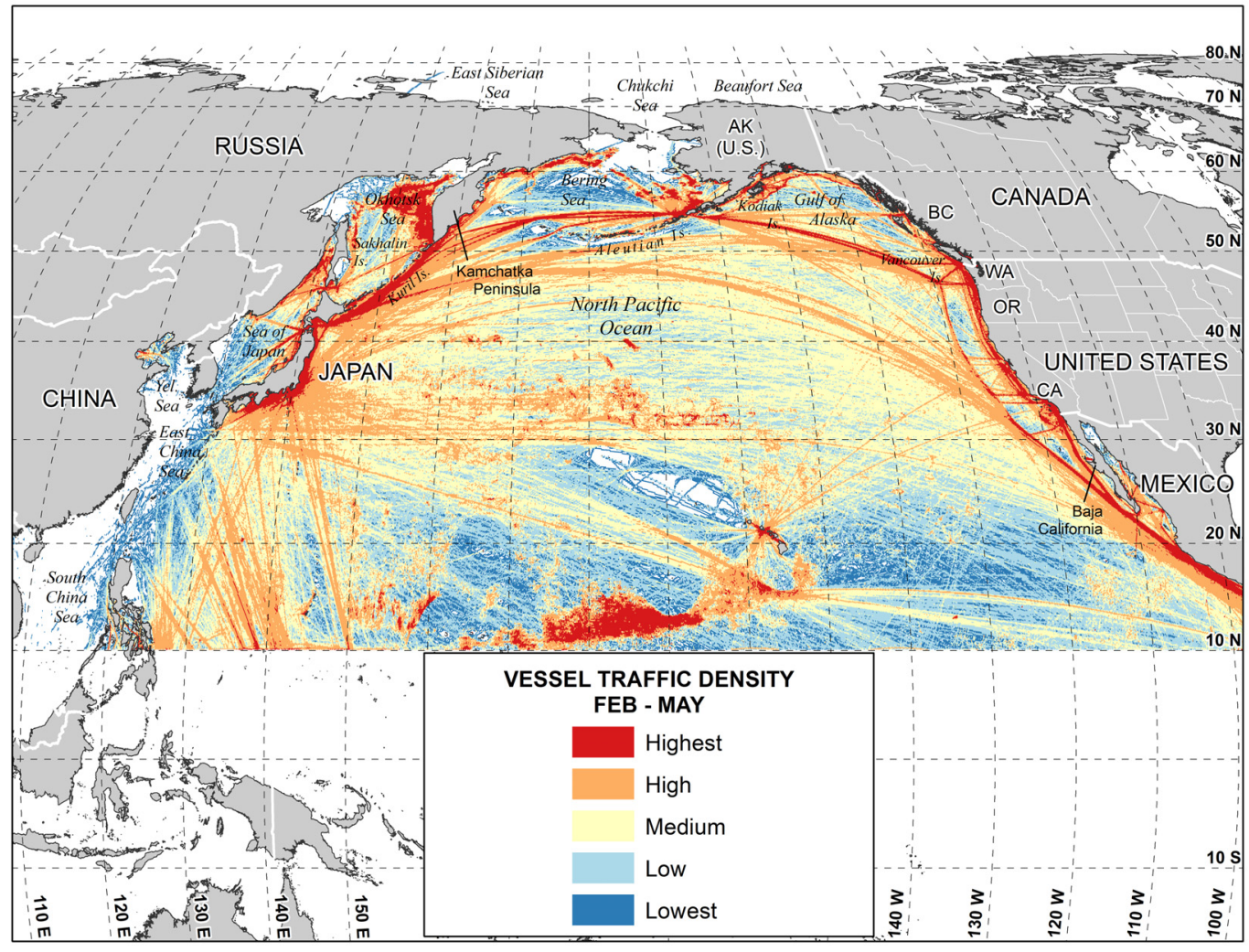

Fig. 1 continued 
a

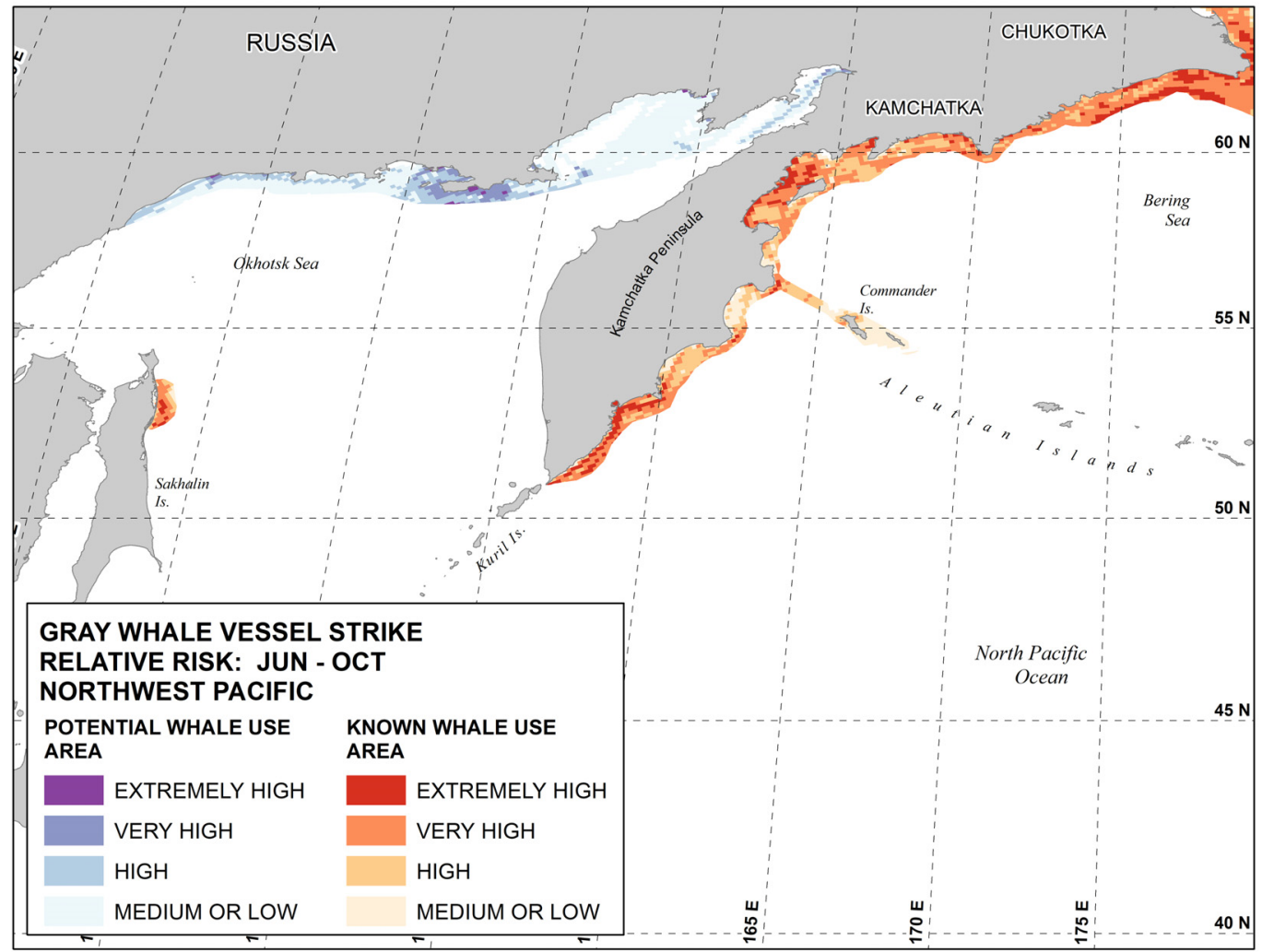

b

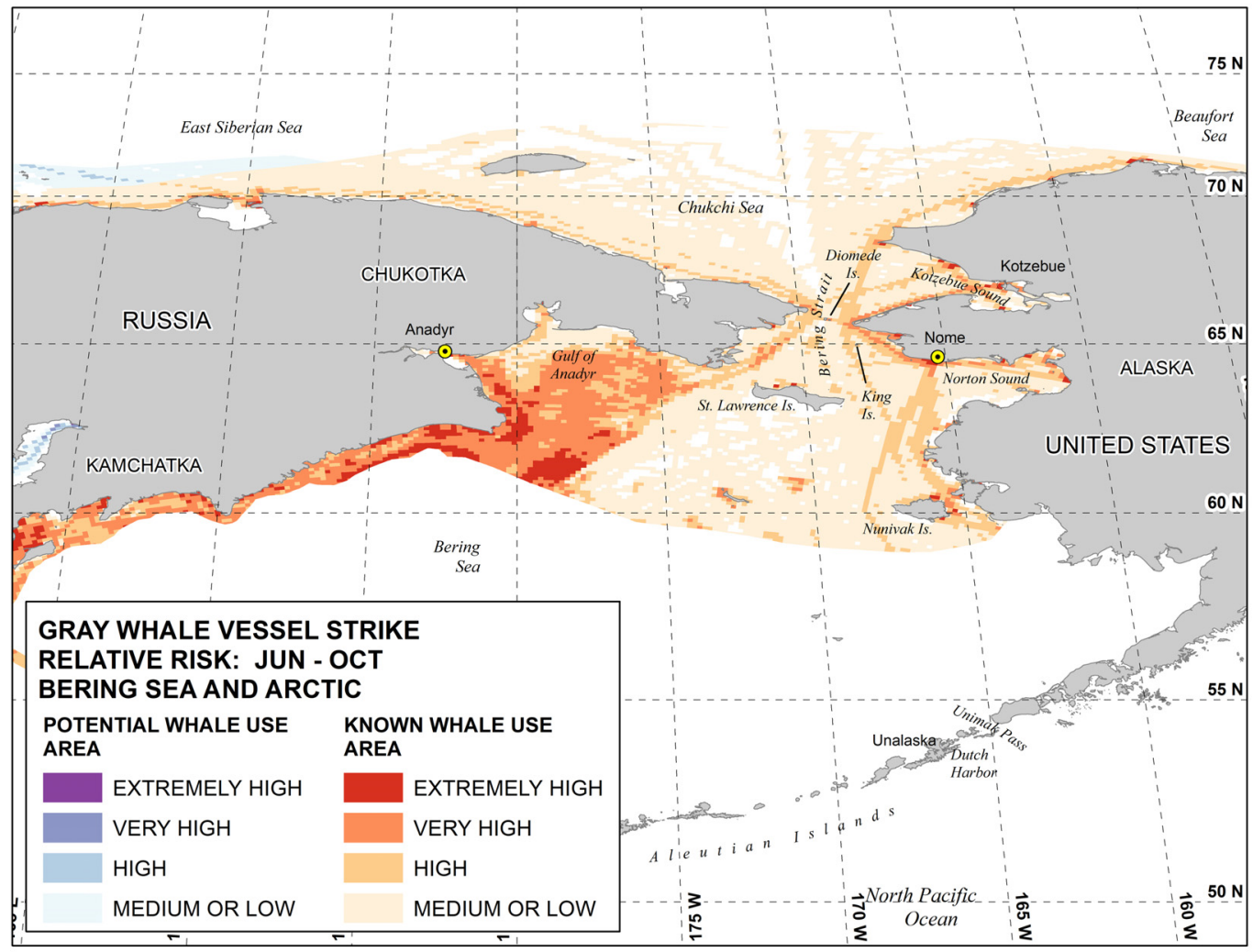

Fig. 2. Region-scale maps of relative vessel-strike risk to gray whales during feeding, wintering, and north- and southbound migration periods: (a) Russian Far East during the feeding period (June-October), (b) Bering and Chukchi Seas during the feeding period (June-October), (c) eastern North Pacific during the feeding period (June-October), (d) Bering and Chukchi Seas, western and central North Pacific, and the Gulf of Alaska during southbound migration (November-January), (e) western North Pacific during southbound migration (November-January), (f) eastern North Pacific during southbound migration (November-January), (g) eastern North Pacific during the wintering period (January-March), (h) Bering and Chukchi Seas, western and central North Pacific, and Gulf of Alaska during northbound migration (February-May), (i) western North Pacific during northbound migration (February-May), and (j) eastern North Pacific during northbound migration (February-May) 
C

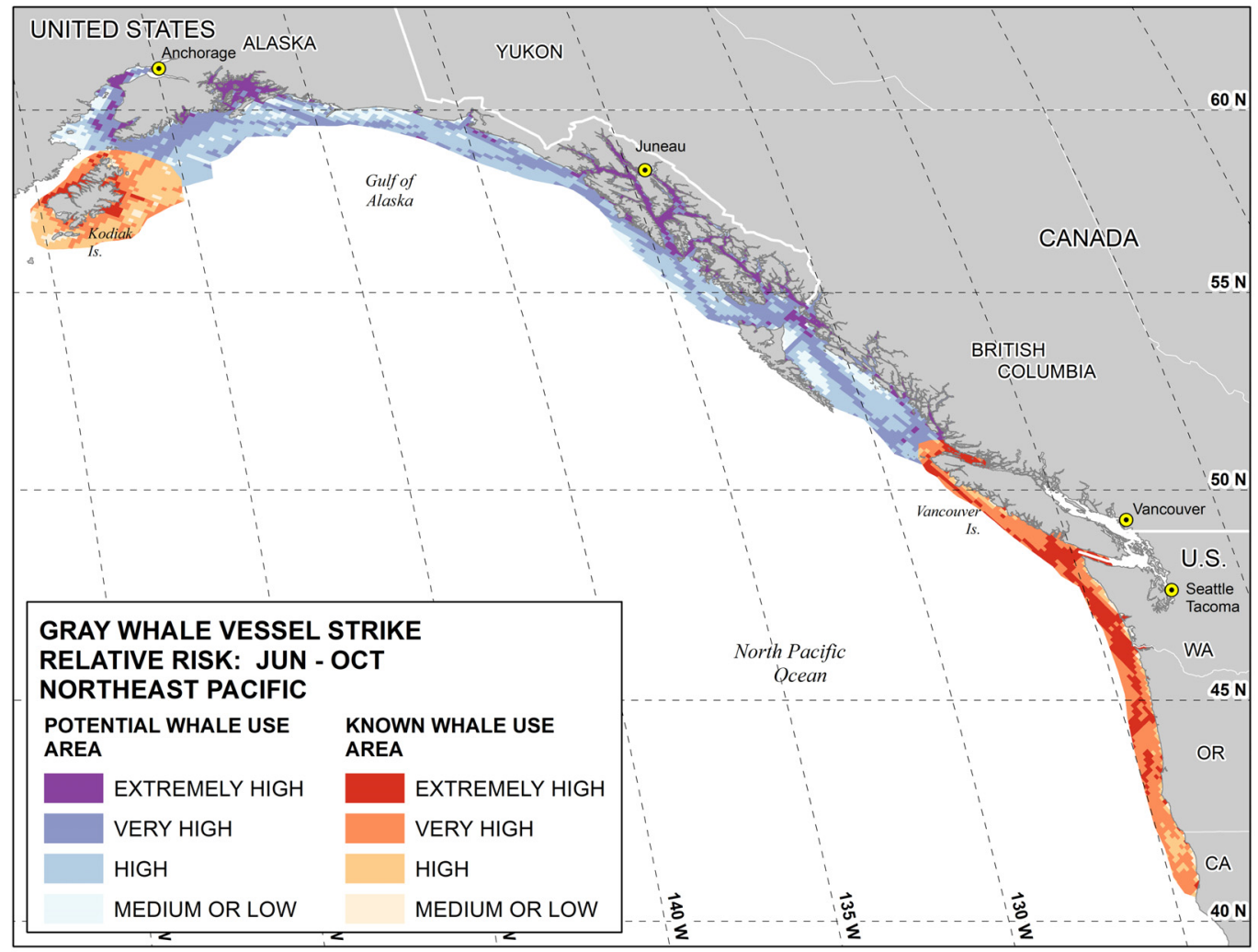

d

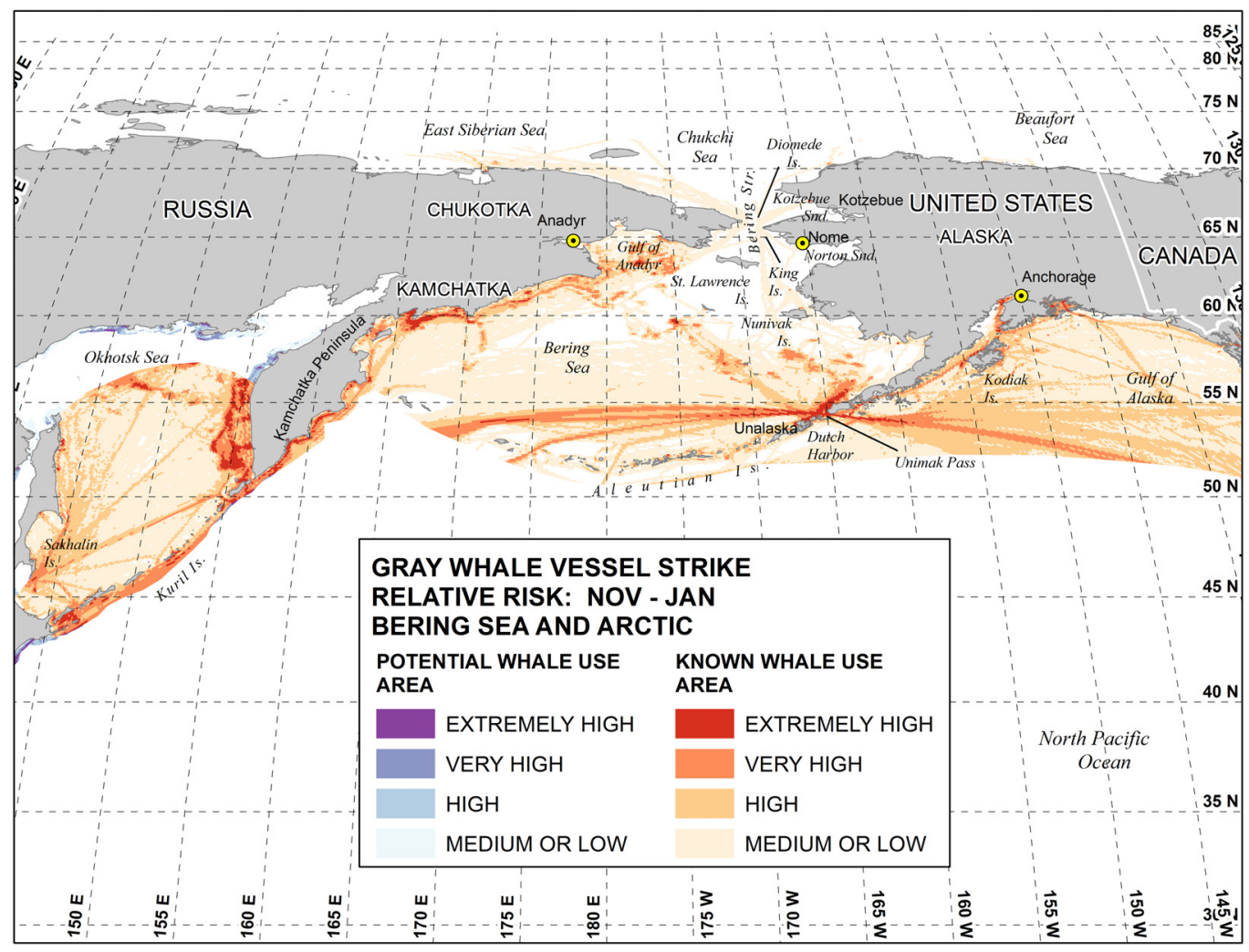

Fig. 2 continued 
e
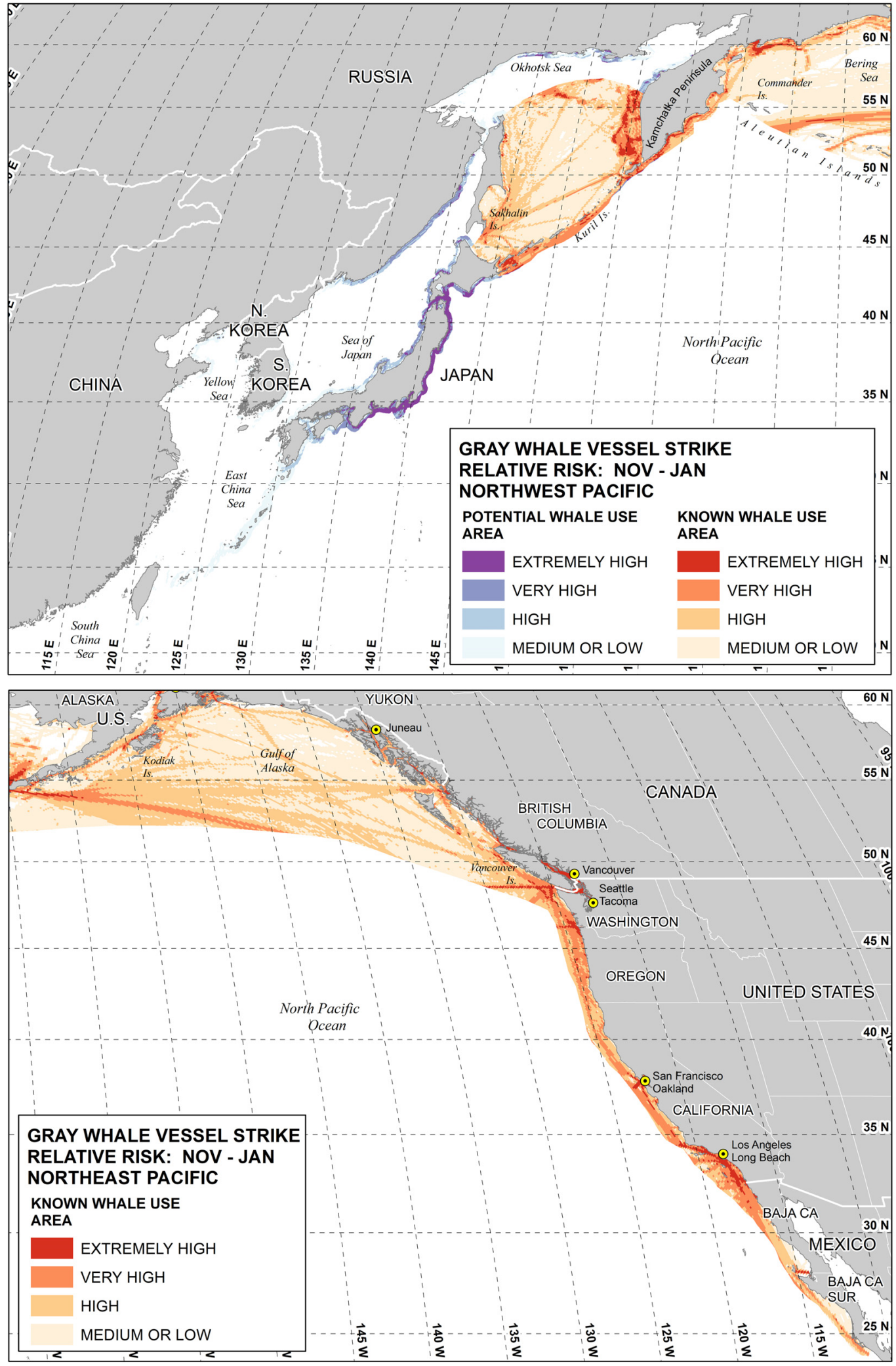

Fig. 2 continued 


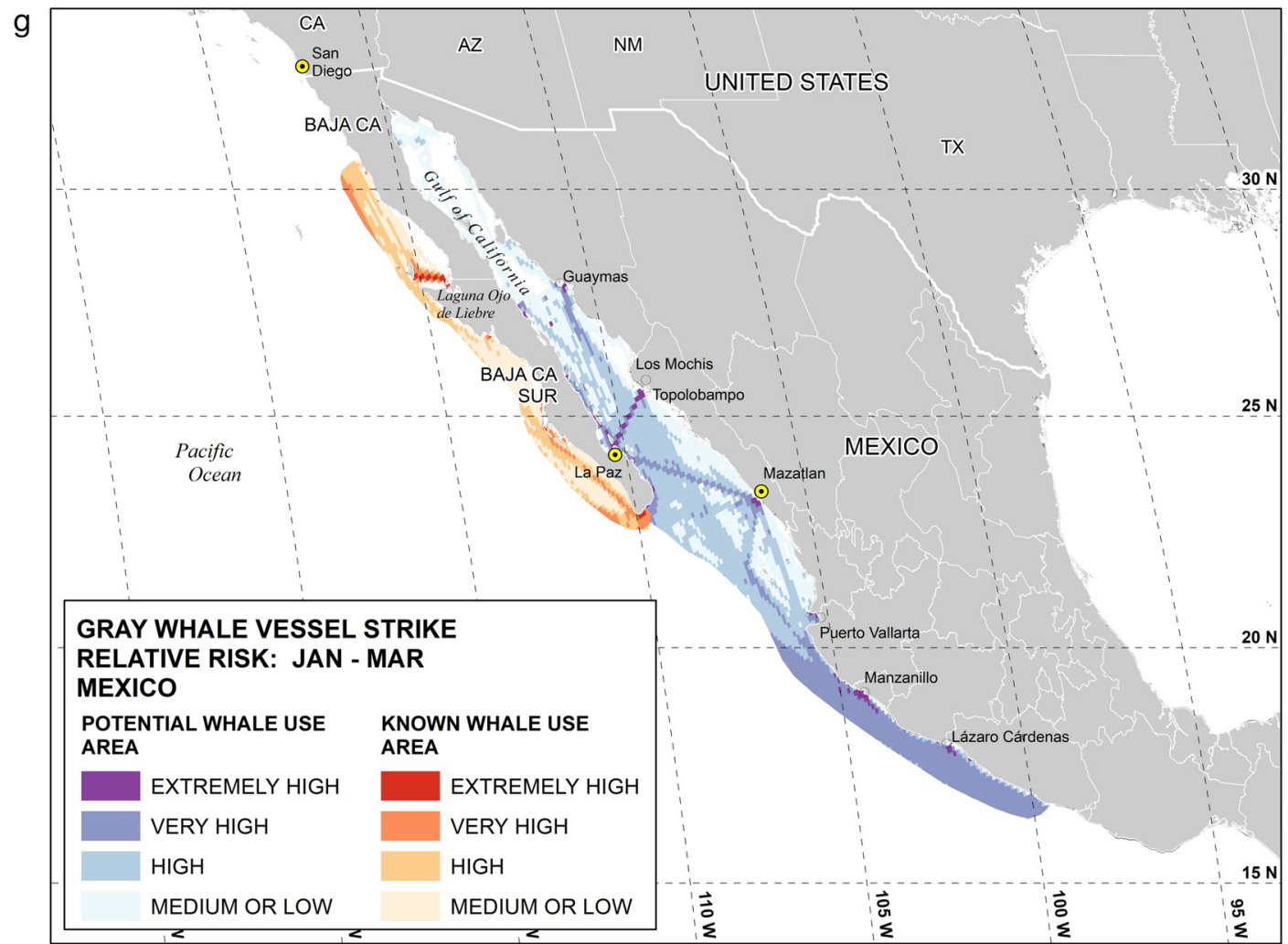

h

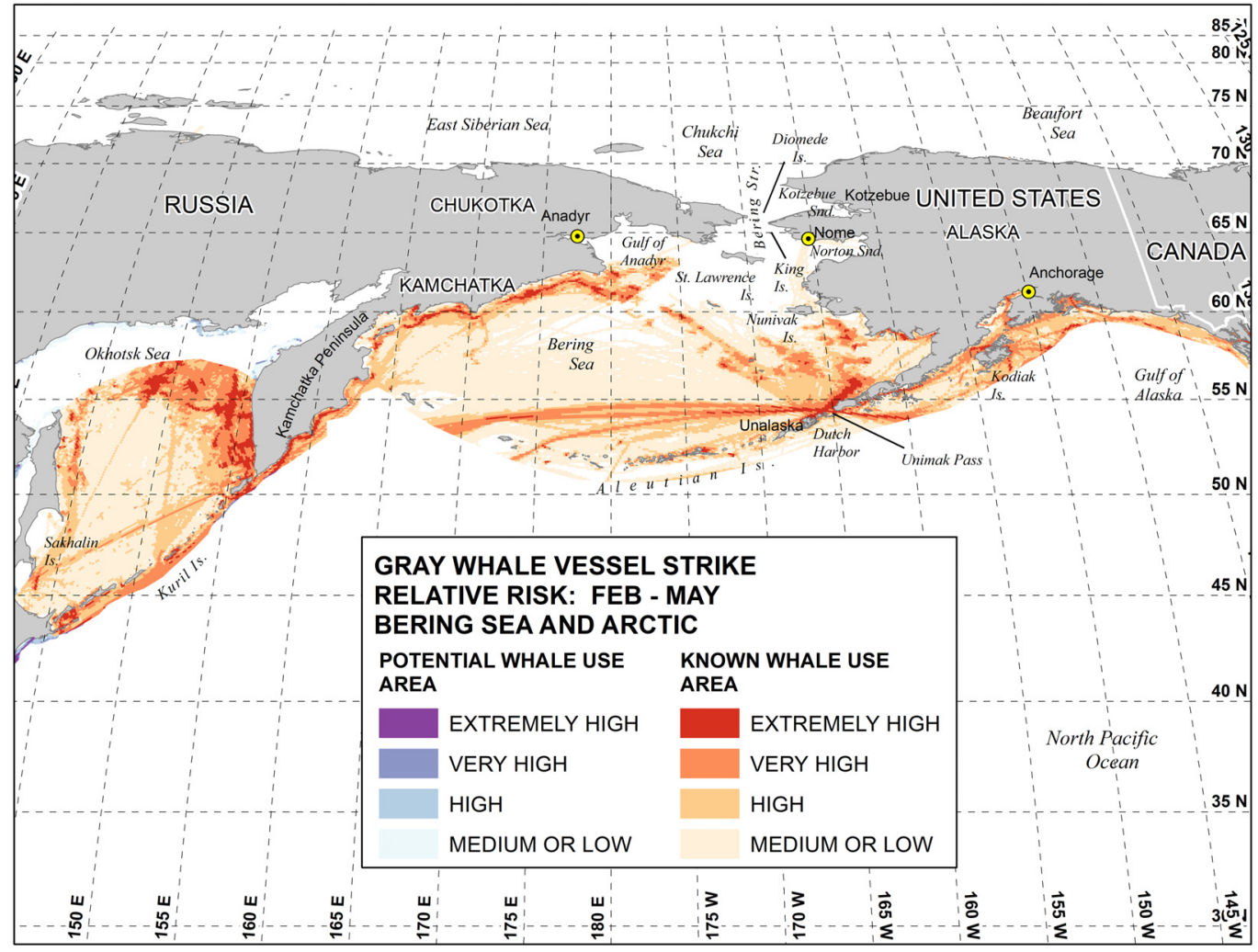

Fig. 2 continued 

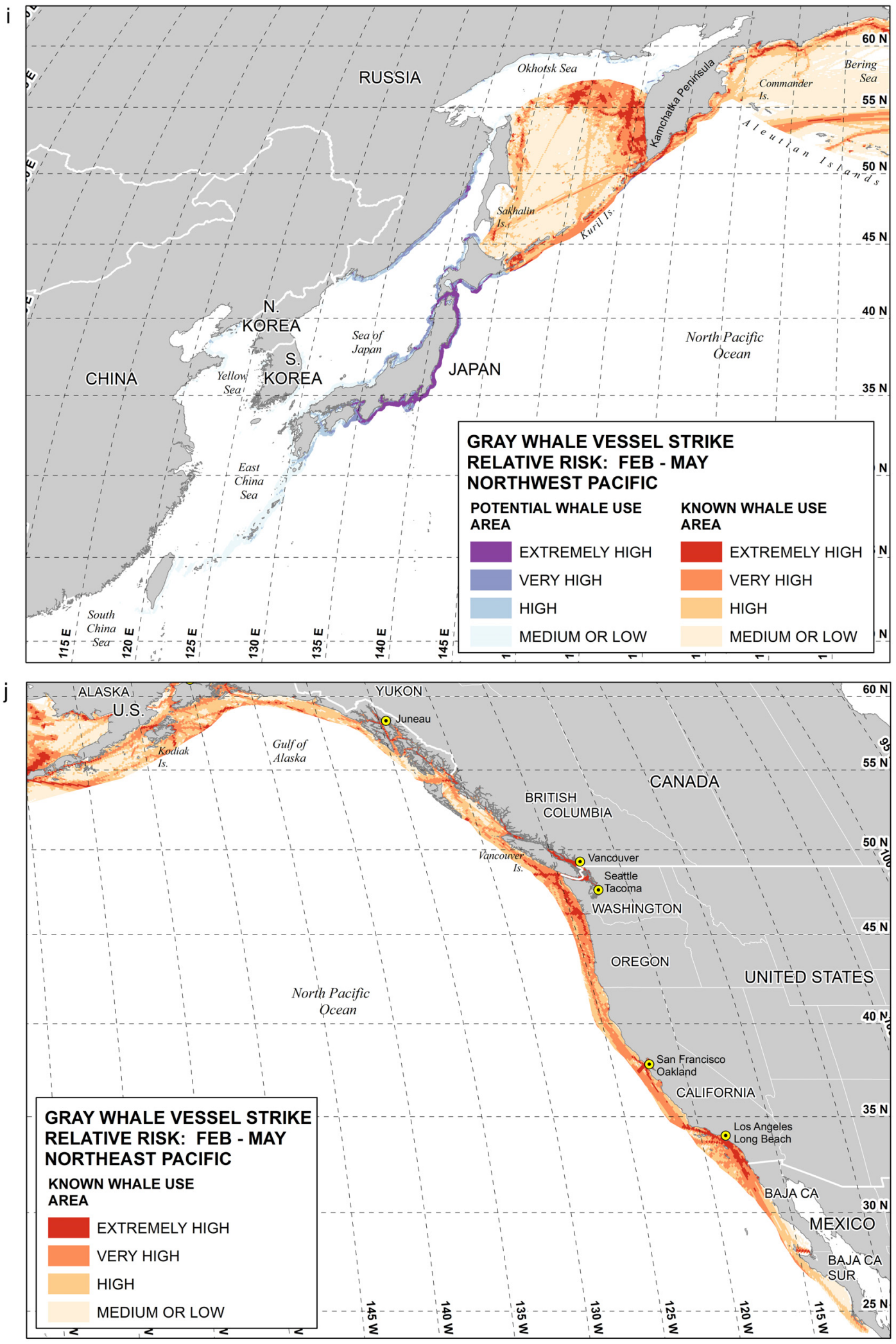

Fig. 2 continued 


\subsection{Southbound migration}

Overall vessel distribution during the southbound migration period generally paralleled that during the feeding period, but densities were somewhat diminished. Waters near Japan, around the Kuril Islands, in portions of the Bering Sea, and along the coast of North America again featured the highest vessel densities (Fig. 1b). There was less use of international trade routes across the central NP than in the feeding period. Discrete areas of very heavy traffic volume were shown in the Okhotsk Sea, along the west coast of Kamchatka, and in the eastern and central Bering Sea. Vessel densities were also very heavy along the entire US coast.

Overall, the southbound (and northbound) migration periods had the greatest relative risk of vessel strikes. Whales were exposed to major intercontinental shipping routes in the southern Bering Sea and Gulf of Alaska (Fig. 2d,h). Vulnerability also appeared to be high near the Kuril Islands and Sakhalin Island and along the Russian coastline of the western Bering Sea (Fig. 2d,e,h,i). Areas of high risk included waters near large port entrances on the North American coastline such as Vancouver, Seattle, San Francisco-Oakland, and Los Angeles-Long Beach.

\subsection{Wintering areas}

In the wintering period, vessel densities were very high along the coast of Japan and around the Kuril Islands, as was also true off the coast of North America including mainland Mexico (Fig. 1c). Areas of very dense traffic occurred in the north-central Okhotsk Sea and along the western Kamchatka peninsula. Similarly dense areas were evident north of the Aleutian Islands and extending into the central and southern Bering Sea. Central NP arcs of international ship transits were reduced relative to summer densities in this period, although the long-distance routes intersecting the Aleutian chain and extending into the southern Bering Sea were still heavily traveled. Heavy ice cover in high latitudes restricts most types of marine transport at this time of the year. Only limited vessel activity was recorded in the Chukchi and Beaufort Seas and parts of the northern Bering Sea (Fig. 1d), presumably because of sea-ice cover and other inhospitable maritime navigation conditions.

Risk appeared limited primarily to areas near the Baja California wintering lagoons and along portions of the western Baja California peninsula (Fig. 2g). Parts of the Mexican mainland coast also appeared to be relatively high-risk to the extent that gray whales occur there in any density. Little could be determined or inferred concerning vessel-strike risk in Southeast Asian waters because the AIS data are limited there (Fig. 1c) and gray whale wintering locations there (if any at present) are not well defined. However, vessel traffic is known to be heavy in Southeast Asia, and given the size of fishing and commercial fleets operating in the region, the few gray whales that may occur there would be at high risk.

\subsection{Northbound migration}

Once again, we found very high vessel densities in the coastal waters of Japan and along the Kuril Islands in this period (Fig. 1d). Dense and geographically broad bands of activity were evident in Russian waters of the western Bering Sea. Except for this concentrated activity in the western Bering Sea, the traffic in the Bering Sea as a whole appeared to be less in this period than at other times. Vessel activity in the Okhotsk Sea was again very heavy, but its distribution appeared to shift eastward and northward relative to other periods. Long-distance trips bisecting the southern Bering Sea and southern Gulf of Alaska and crossing the central NP were once again evident. In the ENP, vessel activity levels were high in coastal areas along much of southern Alaska and along the coastlines of the Gulf of Alaska. Vessel densities were also high near and along the coasts of Canada, the USA, and Mexico.

Concentrations of relatively high vessel-strike risk were identified along parts of the Kuril Island chain and the south coast of Kamchatka, in portions of the Okhotsk Sea and the southern Bering Sea, and near the Aleutian chain (Fig. 2h,i), much like the southbound migration. Risk also appeared to be high in some parts of southeast Alaska. Gray whales were definitely at risk in areas of high vessel density along the entire coast of North America, especially in Washington, Oregon, and California waters and at port entrances (Figs. 1d \& 2j).

\section{DISCUSSION}

\subsection{Use of AIS data}

Although AIS was initially conceived as a technology to reduce at-sea collision risk for ships, the transmissions are widely accessible and have been used in a variety of other maritime safety and environmen- 
tal protection applications (Robards et al. 2016). Constellations of low-orbiting microsatellites now allow acquisition of AIS transmissions from around the world and provide a near-census of vessel movements anywhere on the globe (Høye et al. 2008, Wu et al. 2017). Archived data enable retrospective analyses on a variety of subjects involving vessel movements (Robards et al. 2016).

However, the system is not perfect. Very large data sets can present processing challenges. As the volume of signals transmitted by vessels increases, such as in or near coastal areas, so too does the difficulty of processing satellite AIS data. This can result in data gaps leading to underrepresentation of vessel traffic (Carson-Jackson 2012). In most cases, on-board processing capabilities on satellite platforms are sufficiently robust to provide a data set suitable for analyses of large-scale vessel movement.

AIS equipment (Class B transponders) used by smaller vessels (e.g. less than 300 GT or $20 \mathrm{~m}$ [65 feet] in length) frequenting coastal areas, including portions of our study area, transmit a weaker signal that is often missed by satellites (Taconet et al. 2019). The result is that some signals are dropped or are intermittent (Wu et al. 2017). Finer-scale analyses that include coastal areas would likely benefit from incorporating AIS data received by networks of landbased stations, which are better suited to handle large volumes of transmitted data and are better situated to receive the signals from smaller vessels.

A particular concern is that our analysis revealed a paucity of vessel data in some locations of interest, notably the East China, South China, and Yellow Seas, and to a somewhat lesser extent, the Sea of Japan (data gaps are apparent in Fig. 1). We attribute this to a variety of factors, including the widespread use (especially aboard fishing vessels) of 'Class B' AIS transmitters which have inherently lower transmitting power than 'Class A' systems (Taconet et al. 2019, DHS 2020) thereby limiting detection by satellites. In addition, not all small fishing vessels in the East China, South China, and Yellow Seas broadcast AIS signals (Grande et al. 2019). Moreover, some vessels choose not to use their equipment in order to conceal their activities (Poling 2019, Weimerskirch et al. 2020). As noted earlier, high transmission volumes can occur in some locations, such as the East China Sea, where multiple units in close proximity are transmitting simultaneously, and this can result in incomplete data sets and create challenges in satellite-based processing which lead to a loss of data (Carson-Jackson 2012). However, given our interest in relative vessel-strike risk to whales, we are confident that AIS data provide a rea- sonably accurate assessment of risk at the broad geographical scale of this study. Regardless of any data limitations, it is plainly evident that the risk of vessel strike is high in many locations throughout the range of gray whales and at all times of the year.

\subsection{Feeding areas}

\subsubsection{WNP}

Areas of extremely high relative risk during the feeding period in the WNP (Fig. 2a,b) likely result primarily from fishing, industrial, and coastal shipping operations. Vessels suspected of being associated with Sakhalin Island oil and gas activities appear evident on the eastern Sakhalin coast. Clusters of vessel activity are also evident along much of the eastern Kamchatka coast (Fig. 2a). Concentrations of fishing activity in the western Bering Sea (Fig. 2b) are discussed more fully in Section 4.6.

\subsubsection{ENP}

Extremely high-risk areas along the coast of North America (Fig. 2c) are attributable mainly to large commercial ships near major ports (e.g. Dransfield et al. 2014, Moore et al. 2018) (see Section 4.5 for more discussion on this topic). The small PCFG (about 250 individuals) (Calambokidis et al. 2019) appears to be exposed to heavy traffic in the form of commercial ships (Lagerquist et al. 2019), coastal ferries, and other vessels (Fig. 2c). These whales may also be at risk of strikes by military vessels and in the future by vessels engaged in servicing renewable energy and other facilities near their feeding areas from northern California to British Columbia (Ford et al. 2013, Lagerquist et al. 2019).

Risk also appeared to be very high near Kodiak Island (Fig. 2c) and in surrounding waters. This was likely related to coastal vessel traffic and fishing activities. Scores of commercial and charter fishing vessels home-ported at Kodiak and Dutch Harbor (Unalaska) and targeting Bering Sea species (Witherell et al. 2012) may account for much of the activity in this area.

\subsubsection{Chukchi, East Siberian, and Beaufort Seas}

The occurrence of gray whales in the Chukchi, East Siberian, and Beaufort Seas tends to be geographi- 
cally dispersed, and vessel traffic in these regions appears light relative to other parts of the study area. Relatively high-risk areas in portions of the Chukchi and western Beaufort Seas appear to be restricted primarily to small-port entrances and concentrations of coastal vessel traffic (Fig. 2b). Much of this traffic likely involves re-supply of communities (Huntington et al. 2019), support for local industries (e.g. involving tugs; Fletcher \& Robertson 2016, Adams \& Silber 2017), mining activities (e.g. the large Red Dog mine facility north of Kotzebue, Alaska; Arctic Council 2009, Reeves et al. 2014), and fishing or hunting excursions. Highlatitude shipping routes, such as the Northwest Passage, the Northern Sea Route (e.g. Arctic Council 2009, Aksenov et al. 2017), and the north-south lanes through the Bering Sea (IMO 2017, Huntington et al. 2019), apparently pose relatively little risk to gray whales during the feeding period under current economic and environmental conditions.

\subsection{Southbound and northbound migration}

Whale distribution is broadly similar in south- and northbound migration periods. Vessel-traffic distribution and volume are also comparable (Fig. 1b,d). Consequently, our assessment of relative risk is similar in these 2 periods. Gray whales appear to be at the greatest risk of vessel strike during migration, judging by the geographical extent and number of regional 'hot spots' of vessel-whale overlap.

\subsubsection{WNP}

Gray whales are highly vulnerable when they are present in nearshore shipping routes along the entire coastlines of Japan, the Kuril Islands, and eastern Kamchatka. Very high-risk areas in portions of the Bering Sea (especially the western half) and the Okhotsk Sea appear to be associated with largescale commercial fisheries (Fig. 2d,e). Tagging studies (Mate et al. 2015) indicated that migrating western gray whales pass through a number of the high-risk areas identified here, notably near the Kamchatka peninsula, in the southern Bering Sea, and in nearshore waters of North America.

\subsubsection{ENP}

Much of the risk is in nearshore waters where both vessel volume and whale abundance are high. High- volume container-ship traffic contributes considerable risk along the west coast of North America, particularly at major port entrances (Fig. 2f,j). For example, ports in southern California are among the busiest in the world. Commercial fisheries, and possibly also vessels engaged in the transport of passengers, goods, and supplies, apparently contribute to high-risk zones off southeast Alaska and in the inland waterways of British Columbia (Fig. 2f,j).

\subsubsection{Bering Sea}

International trade routes represent high-risk areas in the southern Bering Sea and in the Gulf of Alaska (Fig. 2d,h). The Unimak Pass in the Aleutian Islands chain serves as a bottleneck for many vessels using intercontinental routes (Schwehr \& McGillivary 2007) and therefore it is also an area of high risk to migrating gray whales (Braham 1984, Silber \& Adams 2019).

\subsection{Wintering areas}

\subsubsection{WNP}

Range-wide vessel-strike risk was lowest in the wintering period. Some of the gray whales that feed in summer near Sakhalin Island (probably < 50 mature individuals; Cooke et al. 2018) migrate to wintering areas off Japan or southern China (Weller et al. 2008, 2016), but the extent to which Southeast Asian waters are used is unknown (Weller et al. 2002, Mate et al. 2015). It is well documented that these waters have heavy vessel traffic (UNCTAD 2016, Zhang et al. 2017), but our AIS data do not reflect this. Given that the number of gray whales present in winter is expected to be small, the overall vessel-strike risk may be low but the risk to any given individual is likely high.

\subsubsection{ENP}

Pockets of relatively high risk were evident near gray whale wintering areas in Mexico, principally at the southern tip of Baja California Sur and near Laguna Ojo de Liebre (Fig. 2g). Much of this traffic may have consisted of pleasure craft, whale-watching boats, and fishing vessels. One of the largest saltwater evaporation facilities in the world is in Laguna Ojo de Liebre (Tovar et al. 2002); a large proportion 
of the refined salt is transported by barge, which may account for much of the risk at this location.

Areas used infrequently or in low numbers by gray whales along the Mexican mainland (south of $20^{\circ} \mathrm{N}$ latitude) and along the west coast of Baja California have substantial vessel traffic, much of it traversing the entire coastline of Central America (Fig. 2g). Within the Gulf of California, another area where gray whales occur infrequently or in low numbers, risk is associated with trips across the gulf to various ports (e.g. ferry and other routes joining La Paz, Mazatlan, and Topolobampo).

\subsection{Risk from commercial shipping}

Fatal vessel strikes of baleen whales are most often attributed to large ships (Laist et al. 2001, Jensen \& Silber 2003). Strikes for which the vessel type was known have usually involved freighters and other large vessel types, including naval vessels (Scordino et al. 2020). Risk-modeling studies have illustrated the vulnerability of whales (e.g. blue, fin, killer, and humpback whales) in port entrances with a high ship volume and in areas of substantial coastal (alongshore) traffic (Williams \& O'Hara 2010, Redfern et al. 2013, 2020, Rockwood et al. 2017, Greig et al. 2020). More than 10000 transits per year were recorded at the ports of Vancouver, Seattle, and Tacoma, combined (Nichol et al. 2017) where vessel strikes are a clear risk to whales (Douglas et al. 2008) (Fig. 3). The ports of Los Angeles and Long Beach are the highestvolume container ship ports in the Western Hemisphere. Together, these 2 ports account for $25 \%$ of North American trade (as measured by twenty-foot

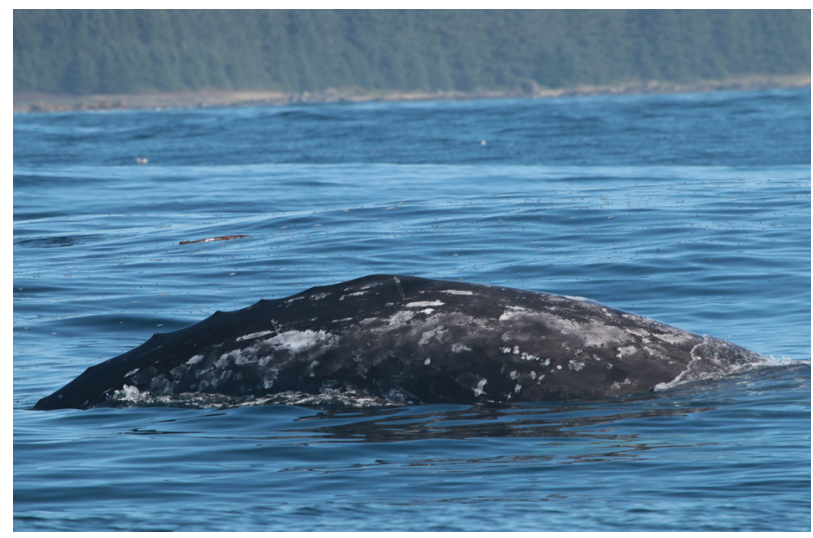

Fig. 3. An apparently healthy (uninjured) gray whale feeding off the Pacific coast of Vancouver Island, British Columbia, Canada, 3 October 2015 shown here for contrast with the images of vessel-struck individuals. Photo credit: NOAA/ NMFS Southwest Fisheries Science Center (permit 14097) [ca. $6.1 \mathrm{~m}$ ] equivalent container units, or TEUs), and along with Seattle, Tacoma, and Oakland/San Francisco comprise 5 of the 10 busiest US ports (www. nglog.com/about-us/the_usas_busiest_ports) (Fig. 4). Waters in and around San Francisco Bay and the Los Angeles and Long Beach port entrances are among the areas with the highest risk of vessel strike for blue, fin, and humpback whales (Rockwood et al. 2017).

Measures to reduce ship-strike mortality have been established on the California coast. Portentrance Traffic Separation Schemes have been re-configured (Dransfield et al. 2014, Moore et al. 2018), and voluntary ship speed-reduction programs are in place (Freedman et al. 2017). These measures, although not specifically aimed at protecting gray whales, likely have reduced the vessel-strike risk to them. In addition, in 2009, 2014, and 2015, California enacted new low-sulfur fuel standards for ships (Redfern et al. 2020); in the same period, the IMO established global and North American low-sulfur standards (https://www. imo.org/en/OurWork/Environment/Pages/Sulphuroxides-(SOx)-\%E2 \% 80 \% 93-Regulation-14 aspx). Vessels responded to the new requirements by adopting routes farther from shore and traveling at significantly lower speeds (reduced speeds appear to be a response to higher fuel prices) (Jensen et al. 2015, Moore et al. 2018). These actions, in turn, reduced the probability of vessel strikes for several whale species (Moore et al. 2018). Gray whales, which occur near shore during the northand southbound phases of their annual migration along the US and British Columbian coasts, have likely been exposed to less risk as a result of these changes in operating practices.

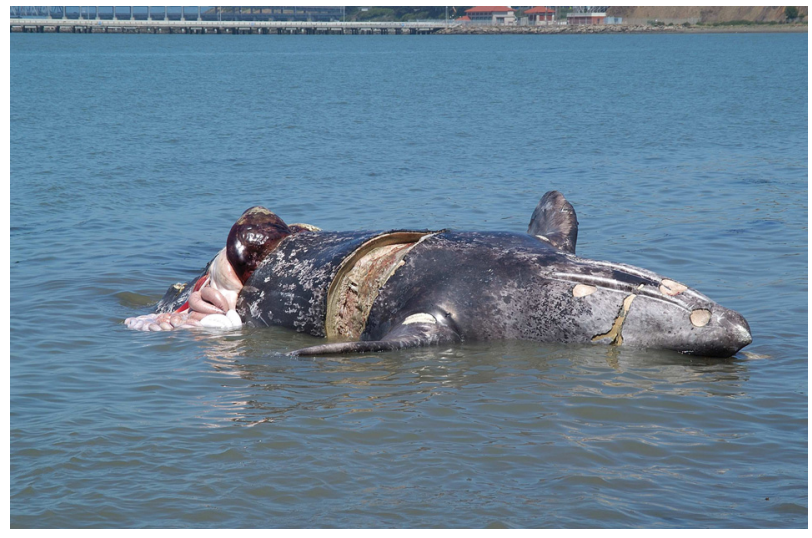

Fig. 4. Vessel-struck gray whale. Injuries on the ventral surface are from very large propeller blades. Intestines are partially extruded. 24 May 2007; San Francisco Bay, California, USA. Photo credit: The Marine Mammal Center (permit 18786-02) 
Our vessel data were limited for the East China, South China, and Yellow Seas. Nonetheless, it is reasonable to assume that the vulnerability to vessel strikes of the few individual gray whales that venture into these seas is very high, particularly around highvolume Asian commercial ports. According to the World Shipping Council, 9 of the world's 10 highestvolume commercial seaports (as measured in TEUs) are situated in East Asia: Shanghai, Singapore, and Hong Kong, among others (www.worldshipping. org/about-the-industry/global-trade/top-50-worldcontainer-ports).

Some of the vessels using these ports are engaged in trans-oceanic voyages, employing primarily Great Circle routes across the NP and in the Bering Sea (Schwehr \& McGillivary 2007). These, too, represent avenues of high risk, primarily during the north- and southbound migration periods and to a lesser or minimal extent during the feeding and wintering periods. Thousands of ships make international passages along these routes each year (Burns \& Poe 2014, Silber \& Adams 2019).

In December 2018, the US Coast Guard implemented routing measures in the Bering Strait and Bering Sea to improve navigational safety and protect marine wildlife. Applying to ships 400 GT and larger, the IMO-approved measures include designated routes for north- and southbound vessel traffic on both sides (Russian and US) of the Diomede Islands and 3 areas to be avoided in waters surrounding Nunivak, Saint Lawrence, and King Islands, Alaska (IMO 2017). These actions may have reduced the risk of vessel strikes of gray whales during the feeding and the north- and southbound migration periods by concentrating generally dispersed vessel transits into designated shipping lanes. Compliance with the measures reportedly was high in 2019 (Fletcher et al. 2020), and this is consistent with use of these routes in the Bering Strait as they appear in our heat maps of vessel traffic (Fig. 1a; summer).

\subsection{Risk from commercial fisheries}

Dense clusters of vessel activity, in contrast to the point-to-point transits characteristic of established shipping routes, often reflect the locations of intense fishing activity (Natale et al. 2015). While typically overshadowed by vessel strikes associated with large, ocean-going container ships and tankers, strikes by fishing vessels (as well as small passenger vessels, pleasure craft, and whale-watching boats) are capable of killing whales and other marine mammals
(Peel et al. 2018, Kelley et al. 2021, Scordino et al. 2020). Strikes by fishing vessels and generally smaller craft might be glancing or result in propeller cuts or other types of injury that are not as often immediately fatal as are the blunt-trauma injuries caused by large vessels (e.g. Neilson et al. 2012) (Fig. 5). Propeller wounds from smaller vessels (Fig. 6) may account for up to a third of all recorded vessel strikes of large whales (Silber et al. 2010). Nonetheless, given the number of vessels in the vast fishing fleets at sea in areas of gray whale occurrence, our analysis suggests that strikes from this vessel class constitute a substantial threat.

In coastal waters of Japan and southern Kamchatka, in the Okhotsk Sea, in waters off Sakhalin Island, and in the western Bering Sea (extending seaward to

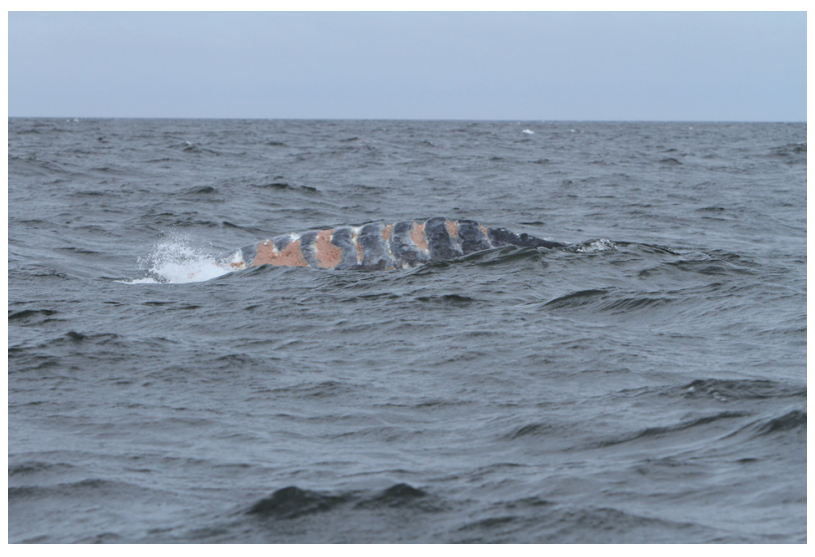

Fig. 5. Gray whale with partially healed wounds along the back caused by large propeller blades. Orange coloration is from aggregations of 'whale lice,' small crustaceans in the family Cyamidae, that commonly infest areas with damaged tissue. 26 June 2019; off Humboldt Bay, California, USA. Photo credit: Jeff K. Jacobsen, VE Enterprises (permit 19091-01)

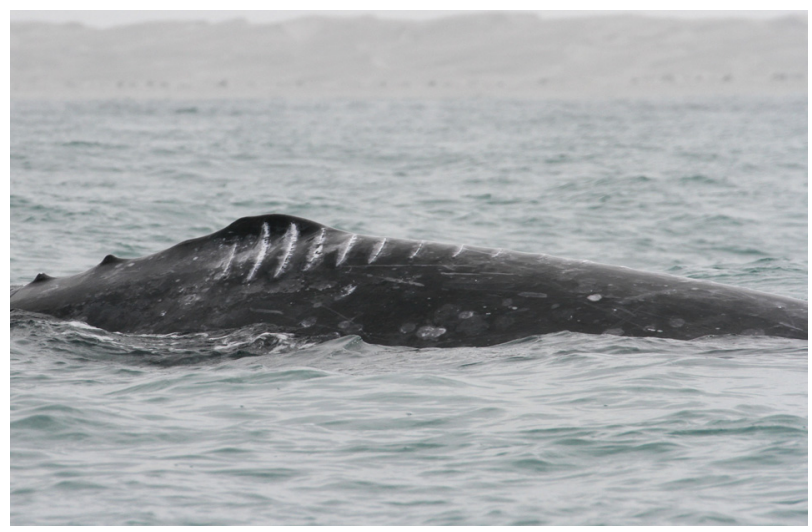

Fig. 6. Female gray whale with propeller marks from a small boat. 29 March 2015; Laguna Guerrero Negro, Baja California, Mexico. Photo credit: Alisa Schulman-Janiger, Natural History Museum of Los Angeles County 
the limit of the Russian exclusive economic zone (EEZ) and including the southern Gulf of Anadyr and northern Kamchatka coast), the eastern Bering Sea southeast of Nunivak Island, and perhaps parts of the northern Gulf of Alaska, gray whales appear to be at particularly high risk of fishery-related strikes during their feeding (Fig. 2b), southbound migration (Fig. 2d,e), and northbound migration (Fig. 2h,i) periods.

Gill nets and set-nets are used extensively in the coastal waters of Japan and the Russian Far East and are known to be associated with gray whale entanglements (Lowry et al. 2018). Fleets of small motorized watercraft usually support these types of fishery. In addition, longline fisheries, principally for Pacific cod Gadus macrocephalus, Pacific halibut Hippoglossus stenolepis, Greenland turbot Reinhardtius hippoglossoides, and Kamchatka flounder Atheresthes evermanni, operate in these same waters at times and in locations that correspond to areas identified in this study as having a high vessel-strike risk. Previous AIS studies have suggested that trawl fisheries for Alaska pollock Gadus chalcogrammus (FAO 2017) and cod (Van Eynde 2017, Grande et al. 2019) are also represented in the apparently high-risk areas of the Okhotsk Sea, around the Kuril Islands, and within the Russian EEZ in the Bering Sea, as may be purse-seine fisheries targeting small pelagic species such as Japanese anchovy Engraulis japonicus and chub mackerel Scomber japonicus (FAO 2017, NPFC 2018). The broad area of relatively high risk that extends seaward to hundreds of kilometers from the Kamchatka Krai and Chukotka coasts is also likely linked to fishing operations (Fletcher \& Robertson 2016), e.g. trawl and purse-seine fisheries (Grande et al. 2019). Bulk cargo-ship and tanker use of this area is also substantial (Fletcher \& Robertson 2016).

Bering Sea fisheries are among the most productive in the world. Fishing vessels made more trips (IMO 2017) and logged more hours than any other vessel type in this sea (Silber \& Adams 2019). Trawl fisheries, mainly targeting pollock, that are active in the central and eastern Bering Sea and on the broad Alaskan and narrow Canadian continental shelves are strongly represented in AIS studies (Iriondo et al. 2019). Longline and pot fisheries for cod and sablefish (black cod Anoplopoma fimbria) are also active in Alaskan waters, including important fishing grounds near Unimak Island (Witherell et al. 2012). Gulf of Alaska trawl fleets target several groundfish species, including pollock, cod, rockfish Sebastes alutus, and Pacific halibut (Iriondo et al. 2019). As mentioned earlier, overall fishing effort is underreported because of diminished AIS capabilities in some parts of the study area (Taconet et al. 2019), therefore the risk of strikes by fishing vessels is likely even higher than indicated by this analysis of relative risk.

\subsection{Risk from non-fishing industrial activities}

High risk from industrial operations besides commercial fishing was evident in several areas. Notable among these are the nearshore waters off Sakhalin Island, where oil and gas development activities, including platform and pipeline construction and geophysical seismic profiling, have been ongoing since the mid-1990s (Weller et al. 2002, Reeves et al. 2005). Both non-renewable and renewable offshore energy infrastructure and operations require high levels of regular vessel support (e.g. Boehlert \& Gill 2010, Halvorsen-Weare et al. 2012); hundreds of vessel trips may be needed every year to service these facilities. In areas for which data are available, workboat vessel classes, including tugboats, logged more hours than other vessel types in the Beaufort and Chukchi Seas (Silber \& Adams 2019). The volume of vessel traffic in support of offshore energy operations is of particular concern in regions where such operations are near to or overlap areas where gray whales aggregate to feed (e.g. Sakhalin) or overwinter, or when the operations intersect migratory routes. Notable efforts have been made by some companies to manage vessel routing and speed in their areas of operation, explicitly to mitigate the risk of striking gray whales (e.g. Exxon Neftegas Limited \& Sakhalin Energy Investment Company Ltd 2018).

Although not captured in our vessel AIS data (for data-limitation reasons described above), vessel operations related to offshore oil and gas resources exist in the East China Sea (e.g. Zhang et al. 2007, EIA 2014) where gray whales may occur. Asia is expected to scale up its refinery capabilities through at least 2050 (EIA 2019) to meet energy consumption demands, which will require networks of large tankers moving raw and refined hydrocarbon materials. In other areas, the transport of hydrocarbon products contributes to the levels of ship traffic. This traffic includes the movement of oil and natural gas (and other products) to refining and distribution centers using the Northern Sea Route across Eurasia (Bogoyavlensky 2013, Silber \& Adams 2019). Tankers and bulk carriers supporting projects in the Russian Arctic traverse various high-latitude routes that may be 
important to whales and other marine mammals (Reeves et al. 2014, Huntington et al. 2019). Although indistinct on the scale used for our maps, traces of portions of this high-latitude Northern Sea Route along the Siberian coast are evident in Fig. 1a. Often accompanied by icebreakers in Arctic waters (thereby adding to the total number of ship transits), some of these transport vessels are bound for Southeast Asian ports (Bambulyak et al. 2015) along routes that apparently contribute to comparatively high vesselstrike risk (Fig. 2d,h).

Risk from energy transport vessels may increase in the future as global energy demands escalate. Increased tanker traffic is expected in Puget Sound, the Juan de Fuca Strait, and other inland waterways near Vancouver and Seattle, where it will intersect important feeding areas and the migratory corridor used by gray whales.

\subsection{Risk from military vessels}

Strikes of large whales by military vessels have been reported in US and Canadian waters fairly often relative to other vessel types (Jensen \& Silber 2003). The data are skewed relative to other vessel types, however, because in the USA, military vessels are required to report whale strikes as a condition of permitting certain naval exercises. Military vessels accounted for a portion of gray whale fatalities (where ship type was known) in records from US waters (Scordino et al. 2020) and it is reasonable to assume that strikes also occur in the EEZs of other nations.

Large military installations exist in many locations around the NP, including the Puget Sound Naval Shipyard (Washington) and Naval Base Ventura County (California) (e.g. Lagerquist et al. 2019). On occasion, large-scale, multinational naval exercises are conducted in the NP (www.military.com/daily-news/2014/ 05/08/23-nations-to-participate-in-maritime-exercise. html). Numerous Navy vessels engaged in training, testing, or transiting between locations travel routinely throughout the NP and in the waters of some national jurisdictions (e.g. Poling 2019), although the location and timing are not always revealed publicly. In addition, not all military vessels engage AIS transponders for reasons of national security (Barco et al. 2012, Poling 2019).

Therefore, while our assessment does not fully account for naval military operations, which may be substantially underreported in the AIS records, military activities at sea unquestionably represent some degree of vessel-strike risk to gray whales.

\subsection{Potentially adverse effects of underwater noise}

The focus of this study is not underwater noise. However, maps of vessel activity can serve as coarse proxies for the extent of underwater ensonification resulting from vessel movements (Redfern et al. 2017). Therefore, the risk maps provided here also reflect levels and locations of gray whale exposure to vessel noise. It appears that gray whales are exposed to vessel noise nearly throughout their range, year-round.

Vessels engaged in routine passage introduce substantial amounts of noise into the water column (Ellison et al. 2012, McKenna et al. 2012). Populationlevel effects on baleen whales of chronic exposure to vessel noise are not well understood (Kight \& Swaddle 2011). However, it is documented that underwater vessel noise can disrupt normal behavior (e.g. Blair et al. 2016), cause at least temporary habitat avoidance (e.g. Castellote et al. 2012), alter intrapopulation acoustic signaling behavior (Moore et al. 2012, Erbe et al. 2019), and negatively affect reproduction (Villegas-Amtmann et al. 2015, 2017).

As is the case with other baleen whale populations, exposure of gray whales to underwater noise may result in displacement from prime habitat (Moore \& Clarke 2002) or impaired communication among individuals, which may compromise vital social interactions (Burnham \& Duffus 2019), including those essential for reproduction (Dahlheim \& Castellote 2016).

\subsection{Population-level implications}

Annual compilations of records of gray whale deaths and serious injuries in US waters (e.g. Carretta et al. 2018, Scordino et al. 2020) generally include multiple instances of known strikes each year. These records are minimum counts, however, as determined by detailed examination of beach-cast carcasses (in some cases, the cause of death could not be determined) and, as such, underrepresent the true extent of strikes for the species. Nonetheless, of the total number of gray whale deaths and serious injuries reported for US waters between 1924 and 2018, 19.1\% were attributed to vessel strikes (IWC 2018, Scordino et al. 2020).

It is reasonable to assume that most vessel-strike deaths of whales go undetected or unreported (Redfern et al. 2013, Rockwood et al. 2017), although the degree of under-detection and under-reporting undoubtedly is subject to numerous variables such as inshore-offshore differences between species and 
aspects of body condition that determine whether a carcass will sink or float (Moore et al. 2020). Carcass recovery, examination, and reporting programs exist to varying degrees in some regions (Korea, Japan, China, Mexico, USA, Canada) within the range of gray whales, but such programs are virtually nonexistent in particularly remote and inaccessible areas such as the Russian Far East (IWC 2018) and portions of Alaska (Scordino et al. 2020).

Studies have estimated the number of actual deaths of various baleen whale species (from all causes) relative to the documented number (i.e. carcasses recovered, or at least observed and reported). Not surprisingly, the estimates of actual deaths have always considerably exceeded the reported numbers. For example, Punt \& Wade (2010) reported a carcass recovery level of $3.9-13.0 \%$ for eastern Pacific gray whales.

Williams et al. (2011) estimated that only $3.4 \%$ of the carcasses of sperm whales Physeter macrocephalus that died during the Deepwater Horizon oil spill in the Gulf of Mexico were recovered. The estimated number of detected and reported deaths of North Atlantic right whales was only $17 \%$ of the deaths that actually occurred in a $20 \mathrm{yr}$ period, most of the investigated deaths (where the cause of death was known) having been ascribed to vessel strikes (Kraus et al. 2005). Rockwood et al. (2017) estimated that vessel-strike deaths of fin, blue, and humpback whales in waters along the US west coast were twice the number reported; and Carretta et al. (2019) estimated that the rate of detection and reporting of vessel-strike deaths relative to the actual number of deaths from vessel strikes ranged from 2 to $10 \%$ for these 3 species. In a study of scarring on live gray whales near Sakhalin Island, Bradford et al. (2009) inferred that at least 3 whales (or $2 \%$ of the study population) had survived at least 1 vessel strike.

In 2013-2018, an average of about 2 vessel strikes of gray whales were documented each year in US waters alone (Scordino et al. 2020). Assuming vessel strikes occurred at comparable rates throughout the species' range, annual range-wide vessel strikes may be in the tens, or perhaps the low hundreds. These possible strike rates notwithstanding, the abundance of gray whales in both the ENP and the WNP has increased over the past several decades (Durban et al. 2017, Cooke et al. 2018). Gray whale populations have grown despite general increases in vessel activity in the NP (Tournadre 2014, UNCTAD 2020). Nonetheless, the maps presented here suggest that vessel-strike risk is relatively high in numerous areas throughout the species' range.
These risk maps alone cannot be expected to be used directly for reducing the risk of ship strikes to gray whales. However, it is hoped that they will constitute a useful step toward understanding the scale and general geography of this risk basin-wide. Precautionary measures already in place in portions of the species' range (e.g. off Sakhalin Island where some oil and gas companies have established traffic corridors, imposed speed limits, and employed observers on their vessels to prevent ship strikes on gray whales, SEIC 2020; vessel routing and speed restrictions in waters off California, Freedman et al. 2017, Moore et al. 2018, Rockwood et al. 2020) should be considered in other areas of apparently strong overlap between vessel and whale density. Moreover, these maps can help guide decisions about where to concentrate quantitative risk analyses for use in designing targeted, empirically based risk reduction and mitigation measures.

\section{CONCLUSIONS}

Gray whales are exposed to the threat of vessel strikes throughout their range and in all seasons. Annual vessel-strike deaths may be in the tens, or the low hundreds. The risk appears greatest during south- and northbound migration periods when much of the population is moving through waters near shore.

While tanker, container, and bulk-carrier ships on long passages represent considerable risk to gray whales, the geographical extent of fishing fleets and the sheer numbers of fishing vessels on the water mean that commercial fisheries could represent a substantial risk, especially in Asia and the Bering Sea. Pleasure craft, ferries, and whale-watching boats likely also pose some risk. Despite the threat of vessel strikes to gray whales described here and elsewhere, the abundance of gray whales in both the ENP and the WNP has increased over the last several decades. The amount of vessel traffic in the NP is generally projected to increase, and the vessel-strike risk to gray whales can be expected to increase accordingly.

Vessel-strike risk maps for gray whales serve as proxies for vessel-strike risk to some other large whales in the NP to the extent that their distributions overlap. Routing measures to reduce the likelihood of vessel strikes on other species in some locations (e.g. blue whales off central California and bowhead whales in the Bering Strait) may incidentally benefit gray whales. Risk maps provided here also serve as 
proxies for the relative extent of exposure of gray whales to underwater vessel noise.

Finally, quantitative vessel-strike risk assessments are warranted, to be followed, where judged appropriate, by the introduction or strengthening of riskreduction measures such as speed limits, prescribed traffic corridors, and areas where vessel travel is restricted.

Acknowledgements. This work was conducted with support provided by the IUCN Western Gray Whale Advisory Panel, which is funded by Sakhalin Energy Investment Company. Kam Chin and David Phinney of the US Department of Transportation's John A. Volpe National Transportation Systems Center have been invaluable partners in building and maintaining the NOAA Fisheries Office of Protected Resources AIS program. Aimee Lang graciously provided spatial data that enabled us to characterize the range of gray whales. We are grateful to NOAA Fisheries for providing supportive work environments for J.D.A. and D.W.W. We thank Anete Berzina-Rodrigo, Shannon Bettridge, James Carretta, Jolie Harrison, Eric Patterson, and Ronald Salz for their thoughtful reviews of this manuscript.

\section{LITERATURE CITED}

Adams J, Silber G (2017) 2015 Vessel activity in the Arctic. NOAA Tech Memo NMFS-OPR-57. US Department of Commerce, NOAA, Silver Spring, MD. https://doi.org/ 10.7289/V5/TMNMFS-OPR-57

Aksenov Y, Popova EE, Yool A, Nurser AJG, Williams TD, Bertino L, Bergh J (2017) On the future navigability of Arctic sea routes: high-resolution projections of the Arctic Ocean and sea ice. Mar Policy 75:300-317

Arctic Council (2009) Arctic marine shipping assessment 2009 report. Publication of the Protection of the Marine Environment Committee. https://oaarchive.arctic-council.org/handle/11374/54

Bambulyak A, Frantzen B, Rautio R (2015) Oil transport from the Russian part of the Barents Region. 2015 status report. The Norwegian Barents Secretariat and Akvaplanniva, Norway. https://www.researchgate.net/publication/ 292966364_Oil_transport_from_the_Russian_part_of_the _Barents_Region_2015_status_report

Barco SG, Lockhart GG, Swingle WM (2012) Using RADAR \& AIS to investigate ship behavior in the Chesapeake Bay ocean approach off of Virginia, USA. Abstract. 2012 Oceans Conference, Hampton Roads, VA, 2012. https: //doi.org/10.1109/OCEANS.2012.6404872

Bettridge S, Baker CS, Barlow J, Clapham PJ and others (2015) Status review of the humpback whale (Megaptera novaeangliae) under the Endangered Species Act. NOAA Tech Memo NOAA-TM-NMFS-SWFSC-540

Blair HB, Merchant ND, Friedlander AS, Wiley DN, Parks SE (2016) Evidence for ship noise impacts on humpback whale foraging behaviour. Biol Lett 12:20160005

Boehlert GW, Gill AB (2010) Environmental and ecological effects of ocean renewable energy development: a current synthesis. Oceanography 23:68-81

Bogoyavlensky V (2013) Oil and gas transportation systems in the Russian Arctic. Strategic environmental impact assessment of development of the Arctic. https://www. arcticinfo.eu/en/features/86-oil-and-gas-transportationsystems-in-the-russian-arctic

* Bowen SL (1974) Probable extinction of the Korean stock of the gray whale (Eschrichtius robustus). J Mammal 55: 208-209

* Bradford AL, Weller DW, Ivashchenko YV, Burdin AM, Brownell RL Jr (2009) Anthropogenic scarring of western gray whales (Eschrichtius robustus). Mar Mamm Sci 25: 161-175

* Braham HW (1984) Distribution and migration of gray whales in Alaska. In: Jones ML, Swartz SL, Leatherwood $\mathrm{S}$ (eds) The gray whale: Eschrichtius robustus. Academic Press, Orlando, FL, p 249-266

* Brodzik MJ, Billingsley B, Haran T, Raup B, Savoie MH (2014) Correction: Brodzik, M. J. et al. EASE-Grid 2.0: incremental but significant improvements for earth-gridded data sets. ISPRS International Journal of Geo-Information 2012 1:32-45. ISPRS Int J Geo-Inf 3:1154-1156. www.mdpi.com/2220-9964/3/3/1154

Burnham R, Duffus D (2019) Gray whale calling response to altered soundscapes driven by whale watching activities in a foraging area. J Ocean Technol 14:85-106

* Burns D, Poe A (2014) Marine vessel traffic in the Aleutians. Aleutian Islands Working Group. https:// aleutianislandsworkinggroup.wordpress.com/2014/09/ 09/marine-vessel-traffic-in-the-aleutians/

Calambokidis J, Steiger GH, Curtice C, Harrison J and others (2015) Biologically important areas for selected cetaceans within US waters - West Coast Region. Aquat Mamm 41: 39-53

Calambokidis J, Pérez A, Laake J (2019) Updated analysis of abundance and population structure of seasonal gray whales in the Pacific Northwest, 1996-2017. Final Report to NOAA, Seattle, WA. https://www.cascadiaresearch.org/ files/publications/Gray_whale_abundance_2017-Rev.pdf

Carretta JV, Helker V, Muto MM, Greenman J and others (2018) Sources of human-related injury and mortality for US Pacific West coast marine mammal stock assessments, 2012-2016. NOAA Tech Memo NMFS-SWFSC601.

Carretta JV, Forney KA, Oleson EM, Weller DW and others (2019) US Pacific marine mammal stock assessments: 2018. NOAA Tech Memo NMFS-SWFSC-617

Carson-Jackson J (2012) Satellite AIS - developing technology or existing capability? J Navig 65:303-321

* Castellote M, Clark CW, Lammers MO (2012) Acoustic and behavioural changes by fin whales (Balaenoptera physalus) in response to shipping and airgun noise. Biol Conserv 147:115-122

Cates K, DeMaster DP, Brownell RL Jr, Silber G and others (2017) Strategic plan to mitigate the impacts of ship strikes on cetacean populations: 2017-2020. International Whaling Commission, Cambridge. https://iwc.int/private/downloads/ dr1UJzeCuNpAWs9Xf9caBw/IWC_Strategic_Plan_on_ Ship_Strikes_Working_Group_FINAL.pdf

* Clapham PJ, Young SB, Brownell RL Jr (1999) Baleen whales: conservation issues and the status of the most endangered populations. Mammal Rev 29:35-60

* Cooke JG, Taylor BL, Reeves R, Brownell RL Jr (2018) Eschrichtius robustus (western subpopulation). The IUCN Red List of Threatened Species 2018: e.T8099A50345475. https://www.iucnredlist.org/species/ 8099/50345475

Dahlheim M, Castellote M (2016) Changes in the acoustic behavior of gray whales Eschrichtius robustus in response to noise. Endang Species Res 31:227-242 
DHS (US Department of Homeland Security) (2020) Types of automatic identification systems (ITU-R M.1371 and IEC STANDARDS). US Coast Guard Navigation Center. https://www.navcen.uscg.gov/?pageName=typesAIS

Wouglas AB, Calambokidis J, Raverty S, Jeffries SJ, Lambourn DM, Norman SA (2008) Incidence of ship strikes of large whales in Washington State. J Mar Biol Assoc UK 88:1121-1132

* Dransfield A, Hines E, McGowan J, Holzman B and others (2014) Where the whales are: using habitat modeling to support changes in shipping regulations within National Marine Sanctuaries in Central California. Endang Species Res 26:39-57

Durban JW, Weller DW, Perryman WL (2017) Gray whale abundance estimates from shore-based counts off California in 2014/15 and 2015/2016. Rep Int Whal Comm Sci Comm SC/A17/GW6

EIA (US Energy Information Administration) (2014) East China Sea. https://www.eia.gov/international/content/ analysis/regions_of_interest/East_China_Sea/east_china _sea.pdf

EIA (2019) International energy outlook 2019 with projections to 2050. US EIA Report IEO2019. https://www.eia. gov/ieo

Ellison WT, Southall BL, Clark CW, Frankel AS (2012) A new context-based approach to assess marine mammal behavioral responses to anthropogenic sounds. Conserv Biol 26:21-28

Erbe C, Marley SA, Schoeman RP, Smith JN, Trigg LE, Embling CB (2019) The effects of ship noise on marine mammals - a review. Front Mar Sci 6:606

Exxon Neftegas Limited, Sakhalin Energy Investment Company Ltd (2018) Report on gray whale monitoring program off northeast Sakhalin Island in 2017. WGWAP19/16-EN. Western Gray Whale Advisory Panel, $19^{\text {th }}$ meeting. https://www.iucn.org/sites/dev/files/wgwap19 _16_en.pdf

FAO (Food and Agriculture Organization of the United Nations) (2017) Fishery and aquaculture statistics 2015. FAO yearbook. FAO, Rome. www.fao.org/3/a-i7989t.pdf

Fletcher S, Robertson T (2016) Bering Sea vessel traffic risk analysis. Report to Ocean Conservancy. Nuka Research and Planning Group. https://oceanconservancy.org/wpcontent/uploads/2017/01/bering-sea-vessel-traffic-1.pdf

Fletcher S, Higman B, Chartier A, Robertson T (2020) Adherence to Bering Strait vessel routing measures in 2019. Nuka Research and Planning Group. https:// www.pewtrusts.org/-/media/assets/2020/04/200131 nukaberingstraitroutingstudy.pdf

F Ford JKB, Durban JW, Ellis GM, Towers JR, Pilkington JF, Barrett-Lennard LG, Andrews RD (2013) New insights into the northward migration route of gray whales between Vancouver Island, British Columbia, and southeastern Alaska. Mar Mamm Sci 29:325-337

Freedman R, Herron S, Byrd M, Birney K and others (2017) The effectiveness of incentivized and non-incentivized vessel speed reduction programs: case study in the Santa Barbara channel. Ocean Coast Manag 148:31-39

* Grande M, Santiago J, Murua H, Granado I and others (2019) FAO Area 61 - AIS-based fishing activity in the Northwest Pacific. In: Taconet M, Kroodsma D, Fernandes JA (eds) Global Atlas of AIS-based fishing activity. Challenges and opportunities. FAO, Rome, p 277-291. www.fao.org/3/ca7012en/ca7012en.pdf

* Greig NC, Hines EM, Cope S, Liu X (2020) Using satellite
AIS to analyze vessel speeds off the coast of Washington State, U.S. as a risk analysis for cetacean-vessel collisions. Front Mar Sci 7:109

* Guazzo R, Helbe TA, D'Spain GL, Weller DW, Wiggins SM, Hildebrand JA (2017) Migratory behavior of eastern North Pacific gray whales tracked using a hydrophone array. PLOS ONE 12:e0185585

Gulland FMD, Pérez-Cortés H, Urgán J, Rojas-Bracho RL (2005) Eastern North Pacific gray whale (Eschrichtius robustus) unusual mortality event, 1999-2000. NOAA Tech Memo NMFS-AFSC-150

* Halvorsen-Weare EE, Fagerholt K, Nonås LM, Asbjørnslett BE (2012) Optimal fleet composition and periodic routing of offshore supply vessels. Eur J Oper Res 223:508-517

* Høye GK, Eriksen T, Meland BJ, Narheim BT (2008) Spacebased AIS for global maritime traffic monitoring. Acta Astronaut 62:240-245

*Huntington HP, Bobbe S, Hartsig A, Knight EJ and others (2019) The role of areas to be avoided in the governance of shipping in the greater Bering Strait region. Mar Policy 110:103564

* IMO (International Maritime Organization) (2017) Establishment of two-way routes and precautionary areas in the Bering Sea and Bering Strait. Sub-committee on Navigation, Communications and Search and Rescue $5^{\text {th }}$ session. NCSR 5/3/7. https://www.navcen.uscg.gov/pdf/ IMO/NCSR_5_3_7.pdf

Iriondo A, Santiago J, Murua H, Granado I and others (2019) FAO Area 67 - AIS-based fishing activity in the Northeast Pacific. In: Taconet M, Kroodsma D, Fernandes JA (eds) Global Atlas of AIS-based fishing activity. Challenges and opportunities. FAO, Rome, p 293-305. www. fao.org/3/ca7012en/ca7012en.pdf)

IUCN (2020) Report of the $20^{\text {th }}$ Meeting of the Western Gray Whale Advisory Panel, 6-8 November 2019, Moscow, Russian Federation. WGWAP-20. https://www.iucn.org/ sites/dev/files/wgwap20_report_final_en.pdf

IWC (International Whaling Commission) (2017) Annex G. Schematic summarising present knowledge of the distribution of gray whales in the North Pacific on a seasonal basis. J Cetacean Res Manag 18 (Suppl): 670-671

IWC (2018) Report of the fourth rangewide workshop on the status of North Pacific gray whales. J Cetacean Res Manag 19(Suppl):519-536

Jensen AS, Silber GK (2003) Large whale ship strike database. NOAA Tech Memo NMFS-OPR-25

* Jensen CM, Hines E, Holzman BA, Moore TJ, Jahncke J, Redfern JV (2015) Spatial and temporal variability in shipping traffic off San Francisco, California. Coast Manag 43:575-588

Kelley DE, Vlasic JP, Brillant SW (2021) Assessing the lethality of ship strikes on whales using simple biophysical models. Mar Mamm Sci 12: 37:251-267

K Kight CR, Swaddle JP (2011) How and why environmental noise impacts animals: an integrative, mechanistic review. Ecol Lett 14:1052-1061

Kraus SD, Brown MW, Caswell H, Clark CW and others (2005) North Atlantic right whales in crisis. Science 309: $561-562$

* Lagerquist BA, Palacios DM, Winsor M, Irvine L, Follett TM, Mate BR (2019) Feeding home ranges of Pacific Coast Feeding Group gray whales. J Wildl Manag 83:925-937

* Laist DW, Knowlton AR, Mead JG, Collet AS, Podesta M (2001) Collisions between ships and whales. Mar Mamm Sci 17:35-75 
Lowry LF, Burkanov VN, Altukhov A, Weller DW, Reeves RR (2018) Entanglement risk to western gray whales from commercial fisheries in the Russian Far East. Endang Species Res 37:133-148

Mate BR, Ilyashenko VY, Bradford AL, Vertyankin VV, Tsidulko GA, Rozhnov VV, Irvine LM (2015) Critically endangered western gray whales migrate to the eastern North Pacific. Biol Lett 11:20150071

McKenna MF, Ross D, Wiggins SM, Hildebrand JA (2012) Underwater radiated noise from modern commercial ships. J Acoust Soc Am 131:92-103

Monnahan CC, Branch TA, Punt AE (2015) Do ship strikes threaten the recovery of endangered eastern North Pacific blue whales? Mar Mamm Sci 31:279-297

Moore MJ, Mitchell GH, Rowles TK, Early G (2020) Dead cetacean? Beach, bloat, float, sink. Front Mar Sci 7:333 doi:10.3389/fmars.2020.00333

Moore SE, Clarke JT (2002) Potential impact of offshore human activities on gray whales (Eschrichtius robustus). J Cetacean Res Manag 4:19-25

Moore SE, Reeves RR, Southall BL, Ragen TJ, Suydam RS, Clark CW (2012) A new framework for assessing the effects of anthropogenic sound on marine mammals in a rapidly changing Arctic. BioScience 62:289-295

Moore TJ, Redfern JV, Carver M, Hastings S, Adams JD, Silber GK (2018) Exploring ship traffic variability off California. Ocean Coast Manag 163:515-527

Natale F, Gibin M, Alessandrini A, Vespe M, Paulrud A (2015) Mapping fishing effort through AIS data. PLOS ONE 10:e0130746

Neilson JL, Gabriele CM, Jensen AS, Jackson K, Straley JM (2012) Summary of reported whale-vessel collisions in Alaskan waters. J Mar Sci 2012:106282

Nichol LM, Wright BM, O'Hara P, Ford JB (2017) Assessing the risk of lethal ship strikes to humpback (Megaptera novaeangliae) and fin (Balaenoptera physalus) whales off the west coast of Vancouver Island, Canada. DFO Can Sci Advis Sec Res Doc 2017/007. https://wavesvagues.dfo-mpo.gc.ca/Library/40619709.pdf

NPFC (North Pacific Fisheries Commission) (2019) NPFC Yearbook 2018. https://www.npfc.int/system/files/201905/Yearbook2018.pdf

Peel D, Smith JN, Childerhouse S (2018) Vessel strike of whales in Australia: the challenges of analysis of historical incident data. Front Mar Sci 5:69

Poling GB (2019) Illuminating the South China Sea's dark fishing fleets. Center for Strategic \& International Studies. https://ocean.csis.org/spotlights/illuminating-thesouth-china-seas-dark-fishing-fleets/

Punt AE, Wade PR (2012) Population status of the eastern North Pacific stock of gray whales in 2009. J Cetacean Res Manag 12:15-28

Redfern JV, McKenna MF, Moore TJ, Calambokidis J and others (2013) Assessing the risk of ships striking large whales in marine spatial planning. Conserv Biol 27:292-302

Redfern JV, Hatch LT, Caldow C, DeAngelis ML and others (2017) Assessing the risk of chronic shipping noise to baleen whales off Southern California, USA. Endang Species Res 32:153-167

Redfern JV, Becker EA, Moore TJ (2020) Effects of variability in ship traffic and whale distributions on the risk of ships striking whales. Front Mar Sci 6:793

Reeves RR, Brownell RL Jr, Burdin A, Cooke JG and others (2005) Impacts of Sakhalin II Phase 2 on western North Pacific gray whales and related biodiversity. Report of the Independent Scientific Review Panel. IUCN-The World Conservation Union, Gland

Reeves RR, Ewins PJ, Agbayani S, Heide-Jørgensen MP and others (2014) Distribution of endemic cetaceans in relation to hydrocarbon development and commercial shipping in a warming Arctic. Mar Policy 44:375-389

Reeves R, Weller D, Cooke J, Donovan G and others (2020) Report on IUCN Western Gray Whale Advisory Panel (WGWAP) work from June 2019 to May 2020. IWC Sci Comm Doc SC/68B/CMP/06 Rev 1

* Rice DW, Wolman AA (1971) The life history and ecology of the gray whale (Eschrichtius robustus). American Society of Mammalogists, Stillwater, OK

* Robards MD, Silber GK, Adams JD, Arroyo J, Lorenzini D, Schwehr K, Amos J (2016) Conservation science and policy implications of the marine vessel Automatic Identification System (AIS) - a review. Bull Mar Sci 92: 75-103

Rockwood RC, Calambokidis J, Jahncke J (2017) High mortality of blue, humpback and fin whales from modeling of vessel collisions on the US West Coast suggests population impacts and insufficient protection. PLOS ONE 12: e0183052

Kockwood RC, Adams J, Silber G, Jahncke J (2020) Estimating effectiveness of speed reduction measures for decreasing whale strike mortality in a high-risk region. Endang Species Res 43:145-166

Rugh DJ (1984) Census of gray whales at Unimak Pass, Alaska, November-December 1977-1979. In: Jones ML, Swartz SL, Leatherwood S (eds) The gray whale: Eschrichtius robustus. Academic Press, Orlando, FL, p 225-248

Schwehr KD, McGillivary PA (2007) Marine ship automatic identification system (AIS) for enhanced coastal security capabilities: an oil spill tracking application. Oceans 2007 Conference, Vancouver, BC. https://scholars.unh. edu/cgi/viewcontent.cgi?article=1387\&context=ccom

Scordino J, Litovka D, Kim, HW, Urban J, Cottrell P (2020) Ship strikes and entanglements of gray whales in the North Pacific Ocean, 1924-2018: revised. Rep Int Whal Comm Sci Comm SC/68B/IST/08

* SEIC (Sakhalin Energy Investment Company Ltd) (2020) Marine Mammal Protection Plan. www.sakhalinenergy. ru/upload/medialibrary/065/1000_S_90_04_P_0048_00_ E_10_ENG_signed.pdf

* Silber GK, Adams JD (2019) Vessel operations in the Arctic, 2015-2017. Front Mar Sci 6:573

Silber GK, Slutsky J, Bettridge S (2010) Hydrodynamics of a ship/whale collision. J Exp Mar Biol Ecol 391:10-19

* Swartz SL (2018) Gray whale: Eschrichtius robustus. In: Würsig B, Thewissen JGM, Kovacs K (eds) Encyclopedia of marine mammals, $3^{\text {rd }}$ edn. Academic Press, Cambridge, MA, p 422-428

* Taconet M, Kroodsma D, Fernandes JA (eds) (2019) Global Atlas of AIS-based fishing activity. Challenges and opportunities. FAO, Rome www.fao.org/3/ca7012en/ ca7012en.pdf

Tetreault BJ (2005) Use of automatic identification system (AIS) for maritime domain awareness (MDA). Oceans Proc IEEE 2:1590-1594

Thomas PO, Reeves RR, Brownell RL (2016) Status of the world's baleen whales. Mar Mamm Sci 32:682-734

Tournadre J (2014) Anthropogenic pressure on the open ocean: the growth of ship traffic revealed by altimeter data analysis. Geophys Res Lett 41:7924-7932 
Tovar LR, Gutierrez E, Cruz G (2002) Fluoride content by ion chromatography using a suppressed conductivity detector and osmolality of bitterns discharged into the Pacific Ocean from a saltworks: feasible causal agents in the mortality of green turtles (Chelonia mydas) in the Ojo de Liebre lagoon, Baja California Sur, Mexico. Anal Sci 18: 1003-1007

Tyurneva OY, Yakovlev YM, Vertyankin VV, Selin NI (2010) The peculiarities of foraging migrations of the KoreanOkhotsk gray whale (Eschrichtius robustus) population in Russian waters of the Far Eastern seas. Russ J Mar Biol 36:117-124

UNCTAD (United Nations Conference on Trade and Development) (2016) Review of maritime transport 2016. UNCTAD/RMT/2016 ISBN 978-92-1-112904-5. United Nations, New York, NY. https://unctad.org/en/ PublicationsLibrary/rmt2016_en.pdf

UNCTAD (2020) Review of maritime transport 2019. UNCTAD/RMT/2019. United Nations, New York, NY. https:// unctad.org/en/PublicationsLibrary/rmt2019_en.pdf

Van Eynde F (2017) Fishery sector overview 2017. Russian and North West Region. Flanders Investment \& Trade Market Survey, Saint Petersburg. https://www. flandersinvestmentandtrade.com/export/sites/trade/files/ market_studies/2017-Russia-Fish-sector-Overview.pdf

Van Waerbeek K, Baker AN, Felix F, Gedamke J and others (2007) Vessel collisions with small cetaceans worldwide and with large whales in the southern hemisphere, an initial assessment. Lat Am J Aquat Mamm 6:43-69

Vanderlaan ASM, Taggart CT (2007) Vessel collisions with whales: the probability of lethal injury based on vessel speed. Mar Mamm Sci 23:144-156

Villegas-Amtmann S, Schwarz LK, Sumich JL, Costa DP (2015) A bioenergetics model to evaluate demographic consequences of disturbance in marine mammals applied to gray whales. Ecosphere 6:1-19

Villegas-Amtmann S, Schwarz LK, Gailey G, Sychenko O, Costa DP (2017) East or west: the energetic cost of being a gray whale and the consequence of losing energy to disturbance. Endang Species Res 34:167-183

Weimerskirch H, Collet J, Corbeau A, Pajot A and others (2020) Ocean sentinel albatrosses locate illegal vessels and provide the first estimate of the extent of nondeclared fishing. Proc Natl Acad Sci USA 117:3006-3014

Weller DW, Burdin AM, Würsig B, Taylor BL, Brownell RL (2002) The western North Pacific gray whale: a review of past exploitation, current status, and potential threats. J Cetacean Res Manag 4:7-12

Weller DW, Bradford AL, Kato A, Bando T, Otani S, Burdin AM, Brownell RL Jr (2008) A photographic match of a western gray whale between Sakhalin Island, Russia, and Honshu, Japan: the first link between the feeding ground and a migratory corridor. J Cetacean Res Manag 10:89-91

Weller DW, Takanawa N, Ohizumi H, Funahashi N and others (2015) Photographic match of a western gray whale between Sakhalin Island, Russia, and the Pacific coast of Japan. Rep Int Whal Comm Sci Comm SC/66a/ BRG17

Weller DW, Takanawa N, Ohizumi H, Funahashi N and others (2016) Gray whale migration in the western North Pacific: further support for a Russia-Japan connection. Rep Int Whal Comm Sci Comm SC/66b/BRG16

Williams R, O'Hara P (2010) Modelling ship strike risk to fin, humpback and killer whales in British Columbia, Canada. J Cetacean Res Manag 11:1-8

Williams R, Gero S, Bejder L, Calambokidis J and others (2011) Underestimating the damage: interpreting cetacean carcass recoveries in the context of the Deepwater Horizon/BP incident. Conserv Lett 4:228-233

Witherell S, Fey M, Fina M (2012) Fishing fleet profiles. North Pacific Fishery Management Council. https://www.npfmc. org/wp-content/PDFdocuments/resources/FleetProfiles 412.pdf

*Wu L, Xu Y, Wang Q, Wang F, Xu Z (2017) Mapping global shipping density from AIS data. J Navig 70:67-81

* Zhang H, Yang S, Wu N, Su X and others (2007) Successful and surprising results for China's first gas hydrate drilling expedition. USDOE-NETL Newsletter, Fire in the Ice, Fall 2007. www.netl.doe.gov/File\%20Library/Research/OilGas/methane\%20hydrates/HMNewsFall07.pdf

* Zhang Y, Yang X, Brown R, Yang L and others (2017) Shipping emissions and their impacts on air quality in China. Sci Total Environ 581-582:186-198 
Appendix. Designation of vessel density and risk categories

Table A1. Values for risk categories used in maps of (a) vessel traffic density and (b) risk (based on vessel traffic density). Range of data values observed for $10 \mathrm{~km} \times 10 \mathrm{~km}$ grid cells throughout the data extent in the Pacific region. Breakpoints were derived as explained in Section 2. Operational hours $\mathrm{d}^{-1}$ were calculated based on the cumulative operational hours and the total number of days in the time period. Equivalent operational hours mo-1 are shown to demonstrate the magnitude relative to a duration (such as $30 \mathrm{~d}$ )

\section{(a) Vessel traffic density}

\begin{tabular}{|c|c|c|c|c|c|c|c|}
\hline \multicolumn{2}{|c|}{$\log _{10}$ (operational $\mathrm{h} \mathrm{d}^{-1}$ ) } & \multicolumn{2}{|c|}{ Operational h d $\mathrm{d}^{-1}$} & \multicolumn{2}{|c|}{ Operational h mo ${ }^{-1}(30 \mathrm{~d})$} & \multirow{2}{*}{$\begin{array}{l}\text { Density } \\
\text { class }\end{array}$} & \multirow{2}{*}{$\begin{array}{l}\text { Ordinal } \\
\text { ranking }\end{array}$} \\
\hline Max & Min & $\operatorname{Max}$ & Min & Max & Min & & \\
\hline 3.056965 & -0.553876 & 1140.158 & 0.279 & 34204.737 & 8.380 & Highest & 1 \\
\hline-0.553877 & -1.167419 & 0.279 & 0.068 & 8.380 & 2.040 & High & 2 \\
\hline-1.16742 & -1.592136 & 0.068 & 0.026 & 2.040 & 0.767 & Medium & 3 \\
\hline-1.592137 & -2.139994 & 0.026 & 0.007 & 0.767 & 0.217 & Low & 4 \\
\hline-2.139995 & -4.954243 & 0.007 & $1.111 \times 10^{-5}$ & 0.217 & $3.333 \times 10^{-4}$ & Lowest & 5 \\
\hline
\end{tabular}

\section{(b) Risk (based on vessel traffic density)}

\begin{tabular}{|c|c|c|c|c|c|c|c|}
\hline \multicolumn{2}{|c|}{$\log _{10}\left(\right.$ operational $\mathrm{h} \mathrm{d}^{-1}$ ) } & \multicolumn{2}{|c|}{ Operational $\mathrm{h} \mathrm{d}^{-1}$} & \multicolumn{2}{|c|}{ Operational h mo $\mathrm{mo}^{-1}(30 \mathrm{~d})$} & \multirow{2}{*}{$\begin{array}{l}\text { Risk } \\
\text { class }\end{array}$} & \multirow{2}{*}{$\begin{array}{l}\text { Risk as re- } \\
\text { lated to vessel } \\
\text { traffic density } \\
\text { ordinal ranking }\end{array}$} \\
\hline Max & Min & $\operatorname{Max}$ & Min & Max & Min & & \\
\hline 3.056965 & 0.143726 & 1140.158 & 1.392 & 34204.737 & 41.768 & Extremely high & $1 \mathrm{a}$ \\
\hline 0.143725 & -0.553876 & 1.392 & 0.279 & 41.768 & 8.380 & Very high & $1 b$ \\
\hline-0.553877 & -1.167419 & 0.279 & 0.068 & 8.380 & 2.040 & High & 2 \\
\hline-1.16742 & -4.954243 & 0.068 & $1.111 \times 10^{-5}$ & 2.040 & $3.333 \times 10^{-4}$ & Medium to low & 3 to 5 \\
\hline
\end{tabular}

Editorial responsibility: Jaume Forcada, Cambridge, UK
Submitted: August 8, 2020; Accepted: November 6, 2020 Proofs received from author(s): January 29, 2021 